\title{
Article \\ Effect Mechanism of Connection Joints in Fabricated Station Structures
}

\author{
Huafei He *(D) and Zhaoping Li
}

Citation: He, H.; Li, Z. Effect Mechanism of Connection Joints in Fabricated Station Structures. Appl. Sci. 2021, 11, 11927. https:// doi.org/10.3390/app112411927

Academic Editors: Qian Fang and Pengfei Li

Received: 24 November 2021 Accepted: 13 December 2021 Published: 15 December 2021

Publisher's Note: MDPI stays neutral with regard to jurisdictional claims in published maps and institutional affiliations.

Copyright: (c) 2021 by the authors. Licensee MDPI, Basel, Switzerland. This article is an open access article distributed under the terms and conditions of the Creative Commons Attribution (CC BY) license (https:// creativecommons.org/licenses/by/ $4.0 /)$.
School of Civil Engineering, Beijing Jiaotong University, Beijing 100044, China; zhpli@bjtu.edu.cn

* Correspondence: he_huafei@163.com

\begin{abstract}
The seismic response of a fabricated subway station is a complex structural connection problem that depends on the mechanical properties of the joints. In order to obtain the optimal joint distribution of a fabricated station structure under earthquake action, three finite element models of a single ring structure of fabricated subway stations assembled with seven, five, and four prefabricated components were proposed. Seismic wave characteristics, peak acceleration, and coupled horizontal and vertical seismic components were considered to study the seismic response of the fabricated subway station structure with different forms of the joint distribution. The dynamic time history method was used to analyze the seismic response in three aspects: structure plastic strain, interlayer relative deformation, and internal force. The damage indexes and residual strength indexes of the joints were offered based on the concrete damage index to evaluate the joints' damage degree. The results showed that the joints of the vault or bottom plate had little influence on the seismic response of the fabricated station structure. The sidewall joints had the obvious seismic response and the most severe damage under horizontal ground motion or coupled ground motion, which were the weak joints of the fabricated station structure. The existence of vertical ground motion aggravated the damage degree of sidewall joints, making the damage occurrence time of sidewall joints earlier and the damage end time extended. On the premise of meeting the mechanical load and site requirements, an assembly scheme with fewer prefabricated components can be selected.
\end{abstract}

Keywords: fabricated subway stations; joint distribution; three-dimensional time history method; seismic response; assembly rate

\section{Introduction}

The construction of urban underground spaces is developing rapidly in China, especially the subway rail transit, which has built 22 lines. The subway stations were designed and demonstrated to have good mechanical properties during the construction process. However, the damage phenomenon observed during the Kobe earthquake in 1995 [1], the Chi-Chi earthquake in 1999, and the Wenchuan earthquake in 2008 [2] indicated that the damage degree of underground structures caused by an earthquake is much higher than that of surface structures. The heaviest damaged one-Daikai station-suffered the total collapse of central columns over a length of $80 \mathrm{~m}$. Furthermore, the station collapse resulted in ground settlement of $2.5 \mathrm{~m}$. Therefore, the seismic study of underground structures is crucial [3-5].

Many scholars began to focus on the damage mechanism of subway stations represented by Daikai Station [6-8], and also showed the necessity of the seismic design of underground structures. For the study of the collapse and destruction disaster of the castin-place station, the two-dimensional numerical model was used to analyze the mechanical properties, which showed that the collapse of the station was caused by the shear failure of the central column [9-11]. Since the two-dimensional model can only consider the middle column as a continuous wall, it cannot reproduce the collapse process of the Daikai station. A 3D finite element numerical analysis was used to simulate reinforced concrete 
structure, analyze the collapse mechanism of Daikai station, and reproduce the failure process $[6,12,13]$. Numerous analyses and investigations found that the center column was the weak location of the cast-in-place frame underground structure [14-16]. Many scholars carried out a large number of seismic design studies of the center column by installing isolation bearings to absorb seismic energy or changing the constraint conditions [17]. At present, the commonly used bearings mainly include rubber bearings and sliding bearings [18-21]. Up to now, the research on seismic design of cast-in-place station structures has been very detailed.

However, the construction method of cast-in-place structures has a significant influence on the environment. Meanwhile, winter construction can face a shutdown period and reduce efficiency. The construction method of fabricated structures can obviously change these situations and conform to the social and economic strategy of energy conservation, environmental protection, and sustainable development. The construction method was successfully applied in constructing subway stations in Germany, Russia, and other countries. The Kyoqiao station of the JR Kyoye Line in Japan was built using double-circle shield tunneling. The Platinum station of Tokyo Line 7 was constructed using triple-circle shield tunneling [22-24]. The Jiangtai Station in Beijing was built using single-circle largediameter shield tunneling and PBA [25-27]. In recent years, China has been speeding up the construction of prefabricated station structures. Five underground stations, including Yuanjiadian station [28] and Hongqi Street Station, were assembled and constructed in Changchun Metro Line 2. Although prefabricated station structures are in full swing, the seismic design of fabricated station structures is still lacking. $\mathrm{Li}$ and $\mathrm{Su}[29,30]$ conducted axial bending test research on the connected joints of prefabricated components and found that the initial stiffness of the joints was large and the flexural stiffness increased with the increase of axial force. Taking Yuanjiadian station structure as the research object, Tao and Ding [31-33] comparatively studied the differences in internal force and deformation between the fabricated and cast-in-place structures through experimental and numerical analyses. The fabricated station structure has better energy dissipation capacity than the cast-in-place station structure, but the lateral deformation resistance is weak. Although some scholars have conducted seismic research on fabricated station structures, the existing literature [29-33] does not give any research results about the weak locations and joints of fabricated station structures.

Based on the projects of Yuanjiadian station in Changchun, Fuchunjiang Road Station in Qingdao, and Longxing station in Shenzhen, China, three-dimensional finite element models of fabricated single-ring station structures assembled with seven, five, and four prefabricated components was proposed in the study. The plastic strain, interlayer relative deformation, and internal force were investigated. The joint damage index and residual strength index were offered based on the concrete damage index to evaluate the joints damage degree. The dynamic time history method was used to compare and analyze the dynamic response characteristics of the fabricated station structure with different joint distribution forms. The effect of the vertical seismic component on the joint damage degree of the fabricated station was studied based on the proposed evaluation method. The research provides scientific evidence for the seismic design and reinforcement of the prefabricated subway station.

\section{Three-Dimensional Viscoelastic Boundary and Verification}

\subsection{Three-Dimensional Viscoelastic Boundary}

The viscoelastic boundary could simulate the elastic recovery effect of a far-field foundation and had good stability under the action of seismic waves with low frequency and high frequency in previous studies [34-36]. In the seismic analysis of underground structures, the finite soil range is usually cut off and a reasonable artificial boundary is set to simulate the seismic reflection and damping effect of an infinite foundation. The equivalent nodal force of an artificial boundary and artificial viscoelastic boundary are combined, and the application of an equivalent nodal force on the artificial boundary is realized. The key 
to the artificial viscoelastic boundary is to choose a proper spring stiffness and damping coefficient. $K$ and $C$ are the spring stiffness and damping coefficients, respectively, which can be expressed as follows according to Liu and He's research [35,37].

In the tangential direction:

$$
K_{\mathrm{BN}}=\alpha_{\mathrm{N}} \frac{G}{R} \quad C_{\mathrm{BN}}=\rho c_{\mathrm{p}}
$$

In the normal direction:

$$
K_{\mathrm{BT}}=\alpha_{\mathrm{T}} \frac{G}{R} \quad C_{\mathrm{BT}}=\rho c_{\mathrm{s}}
$$

where $K_{\mathrm{BN}}, K_{\mathrm{BT}}, C_{\mathrm{BN}}$, and $C_{\mathrm{BT}}$ are the spring stiffness and damping coefficients in the normal and tangential directions of the artificial boundary when the influence area of the boundary node is 1 . $E, G$, and $v$ are the elastic modulus, shear modulus, and Poisson's ratio of the far-field foundation; $\lambda$ and $\mu$ are lame constants of the far-field foundation; $\rho$ is the mass density of the far-field foundation; $R$ is the distance from the scattered wave source to the artificial boundary. $c_{\mathrm{p}}$ and $c_{\mathrm{s}}$ are the compression wave and shear wave velocities of the far-field foundation. The parameters $\alpha_{\mathrm{N}} \alpha_{\mathrm{T}}, A$, and $B$, are 1.33, 0.67, 0.9, and 1.1, respectively.

$$
\begin{gathered}
c_{\mathrm{p}}=\sqrt{\frac{\lambda+2 \mu}{\rho}}=\sqrt{\frac{(1-v) E}{(1+v)(1-2 v) \rho}} \\
c_{\mathrm{s}}=\sqrt{\frac{\mu}{\rho}}=\sqrt{\frac{E}{2(1+v) \rho}}
\end{gathered}
$$

\subsection{Verification of the Artificial Viscoelastic Boundary}

In the validation example of the artificial viscoelastic boundary, a 3D uniform semiinfinite elastic FE model is illustrated in Figure 1. Point A is the midpoint of the top boundary and point $\mathrm{B}$ is the midpoint of the bottom boundary.

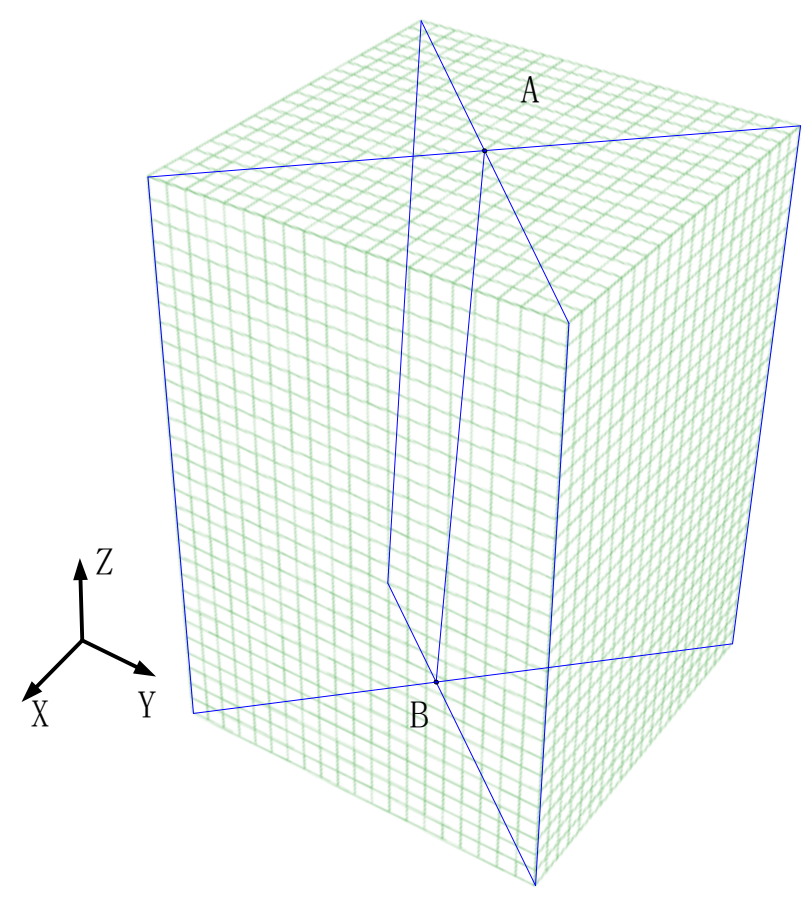

Figure 1. FE model for the validation example.

A finite area of $400 \mathrm{~m}$ in length and width and $600 \mathrm{~m}$ in height was cut from a uniform three-dimensional elastic half-space. The elastic modulus of the model was $4.88 \mathrm{GPa}$, the density was $2000 \mathrm{~kg} / \mathrm{m}^{3}$, and Poisson's ratio was 0.22 . The incident $p$-wave velocity was 
$1669.05 \mathrm{~m} / \mathrm{s}$ and the S-wave velocity was $1000 \mathrm{~m} / \mathrm{s}$. The time step was taken as $0.01 \mathrm{~s}$. The grid size was $20 \mathrm{~m}$ in three directions, with 13,671 nodes and 12,000 hexahedral cells. In the numerical analysis, the input of seismic waves was implemented into ABAQUS [38] using a displacement time history. The displacement time history of the Dirac impulse function was imposed on the bottom boundary of the model. The displacement time history of the Dirac impulse function can be expressed as:

$$
P(\tau)=16 P_{0}\left[G(\tau)-4 G\left(\tau-\frac{1}{4}\right)+6 G\left(\tau-\frac{1}{2}\right)-4 G\left(\tau-\frac{3}{4}\right)+G(\tau-1)\right]
$$

where $G(\tau)=\tau^{3} H(\tau), \tau=t / T_{0}\left(T_{0}=1 \mathrm{~s}\right), P_{0}=0.5 \mathrm{~m}$, and $H(\tau)$ is the Heaviside function.

The calculated and theoretical values for points A and B are given in Figure 2. The numerical and theoretical solutions were compared for each condition, and the results showed that they were very consistent. The time history and amplitude of the S and P waves in the numerical verification were pretty accurate, which showed the validity of the wave input method used in this study.

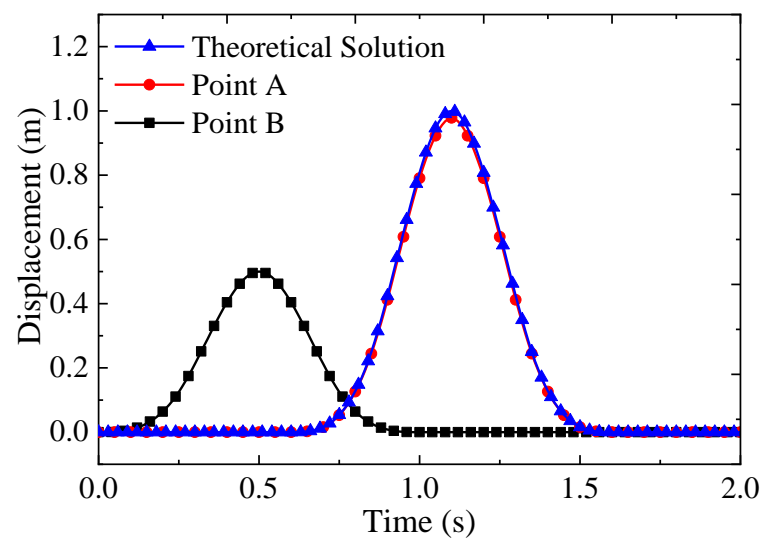

(a) S-wave incidence direction

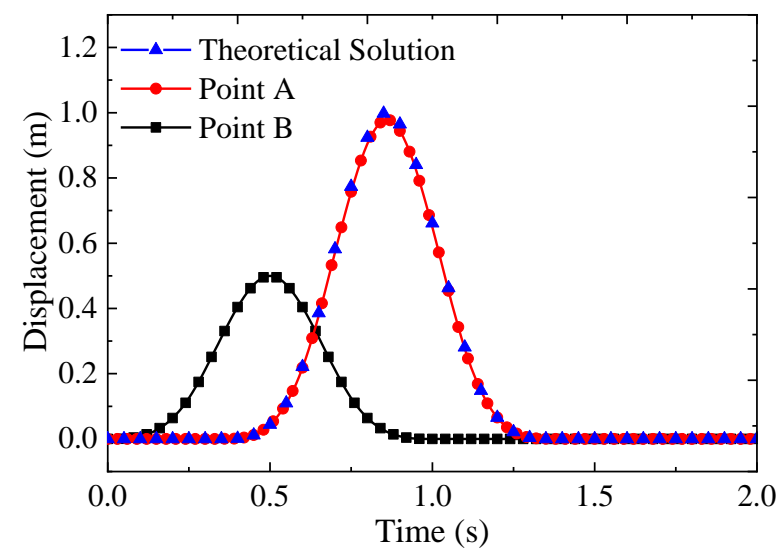

(b) P-wave incidence direction

Figure 2. Comparison of the displacement time history at point A and point B.

\section{Structure Introduction and Ground Motion Input}

\subsection{Structure Introduction}

Three FE models of underground structures were employed with three kinds of joint distribution forms and were simulated using the fabricated station structure under construction or already built. The first fully prefabricated subway station, namely, Yuanjidian Station [28], Changchun city, Jilin province, China, is a single-arch double-layer horseshoe structure with a cover depth of $3.5 \mathrm{~m}$, a total width of $20.5 \mathrm{~m}$, and a total height of $17.45 \mathrm{~m}$. The standard ring width of the station structure is $2 \mathrm{~m}$ and was assembled using seven precast components. The physical and mechanical parameters of the structures and soil are shown in Tables 1 and 2.

Table 1. The physical and mechanical parameters of the structures.

\begin{tabular}{ccccc}
\hline Structural Component & $\begin{array}{c}\text { Strength } \\
\text { Grade }\end{array}$ & $\begin{array}{c}\text { Elastic Modulus } \\
\text { (GPa) }\end{array}$ & $\begin{array}{c}\text { Poisson's } \\
\text { Ratio }\end{array}$ & $\begin{array}{c}\text { Density } \\
\text { (kg. m }\end{array}$ \\
\hline Prefabricated component & C50 & 34.5 & 0.25 & 2450 \\
Middle plate & C40 & 32.5 & 0.25 & 2450 \\
Middle column & C40 & 32.5 & 0.25 & 2450 \\
Steel & HRB400 & 210 & 0.30 & 7850 \\
\hline
\end{tabular}


Table 2. The physical and mechanical parameters of the soil.

\begin{tabular}{cccccc}
\hline $\begin{array}{c}\text { Soil Layer } \\
\text { Number }\end{array}$ & Name & $\begin{array}{c}\text { Thickness } \\
(\mathbf{m})\end{array}$ & $\begin{array}{c}\text { Density } \\
\left.\mathbf{( k g} \cdot \mathbf{m}^{-\mathbf{3}}\right)\end{array}$ & $\begin{array}{c}\text { Shear Wave } \\
\text { Velocity } \\
\left(\mathbf{m} \cdot \mathbf{s}^{-\mathbf{1})}\right.\end{array}$ & $\begin{array}{c}\text { Poisson's } \\
\text { Ratio }\end{array}$ \\
\hline 1 & Miscellaneous fill & 3 & 1900 & 115 & 0.37 \\
2 & Silty clay & 5 & 1950 & 158 & 0.32 \\
3 & $\begin{array}{c}\text { Silty clay } \\
\text { Weathered } \\
\text { mudstone }\end{array}$ & 37 & 1980 & 299 & 0.27 \\
\hline
\end{tabular}

Qingdao metro station, China, was optimized and adjusted based on the prefabricated scheme of Changchun metro, as shown in Figure 3a. The mainlining structure was composed of five precast components, among which, the bottom plate was adjusted from three to one, as shown in Figure 3b. The design of Longxing Station of Shenzhen Metro, China, made use of further optimization based on the assembled scheme of Qingdao metro. The two components of the vault were adjusted to one, and the single ring structure was assembled using only four large prefabricated components, as shown in Figure 3c. The construction process [28] of Yuanjidian Station is shown in Figure 4. The sizes of the three models are not exactly the same. However, in order to focus on the impact of the connecting joints of the vault and the bottom plate on the seismic response of the fabricated station structure, the size of Changchun subway station was taken as the prototype to model Qingdao Subway Station and Shenzhen Subway Station. The fabricated station structure is composed of single ring structures assembled using reinforcement bundles. This study only focused on the lateral seismic response of the single-ring structure and did not consider the longitudinal seismic response of the station structure.

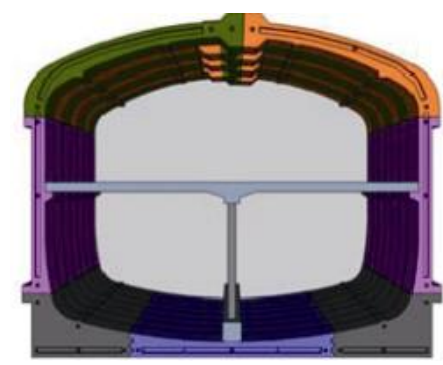

(a) Yuanjiadian Station structure

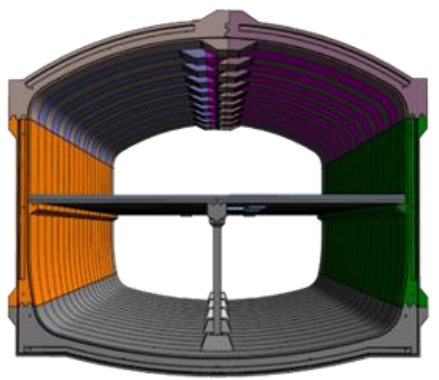

(b) Fuchunjiang Road Station structure

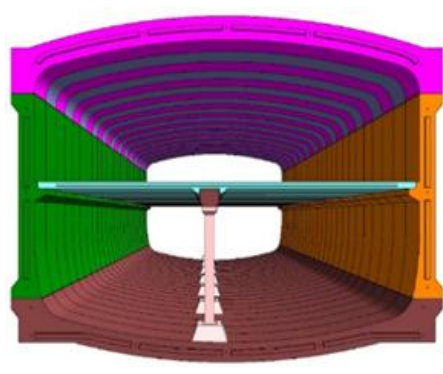

(c) Longxing Station structure

Figure 3. Fabricated subway station structures with different joint distributions.

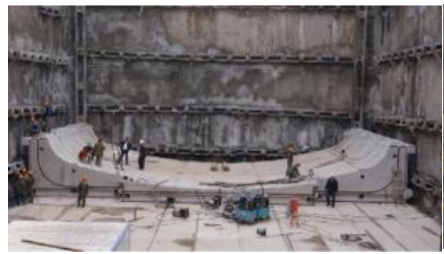

(a) Bottom assembly

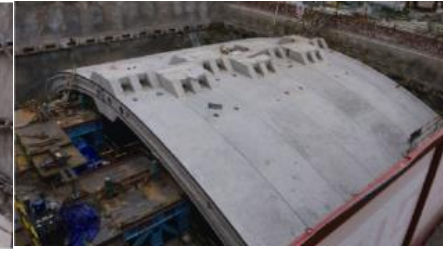

(b) Top arch assembly

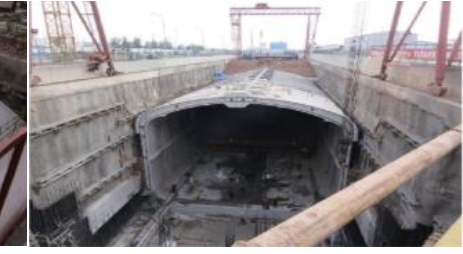

(c) Completion of structure

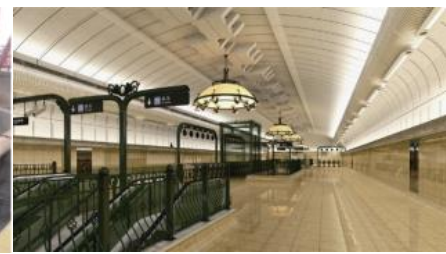

(d) Decoration rendering

Figure 4. The construction process of the fabricated station structure of Changchun Yuanjidian Station, China.

\subsection{The 3D Finite Element Models of Fabricated Station Structures}

The three-dimensional finite element model of the soil-subway station structure system was established in ABAQUS. In order to pay attention to the influence of joint distributions on the fabricated station structure, the finite element model of Changchun Yuanjiadian station (defined as the CC model) was first established. Then, the contact surface of prefabricated blocks A and B was simulated with the "Tie" feature in Fuchunjiang 
Road Station of Qingdao (defined as the QD model). Finally, the "Tie" feature was used to simulate Shenzhen Longxing Station (defined as the SZ model) regarding the contact surface of the prefabricated blocks D and E. The CC model was used as the fundamental model, where its finite element model and prefabricated components are shown in Figure 5. The station's main body is a single-arch and double-layer horseshoe structure, with a total width of $20.5 \mathrm{~m}$ and a total height of $17.45 \mathrm{~m}$. The standard ring width of the station structure is $2 \mathrm{~m}$, and the single ring structure is assembled from seven blocks of $\mathrm{A}, \mathrm{B}$ (left $\mathrm{BL}$, right $\mathrm{BR}$ ), $\mathrm{C}$ (left $\mathrm{CL}$, right $\mathrm{CR}$ ), $\mathrm{D}$, and $\mathrm{E}$ blocks. The connection joints of the prefabricated components mainly include three parts: vault joint (D-E joint), bottom plate joints (A-BR joint, A-BL joint), and sidewall joints (BR-CR joint, BL-CL joint, $\mathrm{CR}-\mathrm{D}$ joint, CL-E joint).

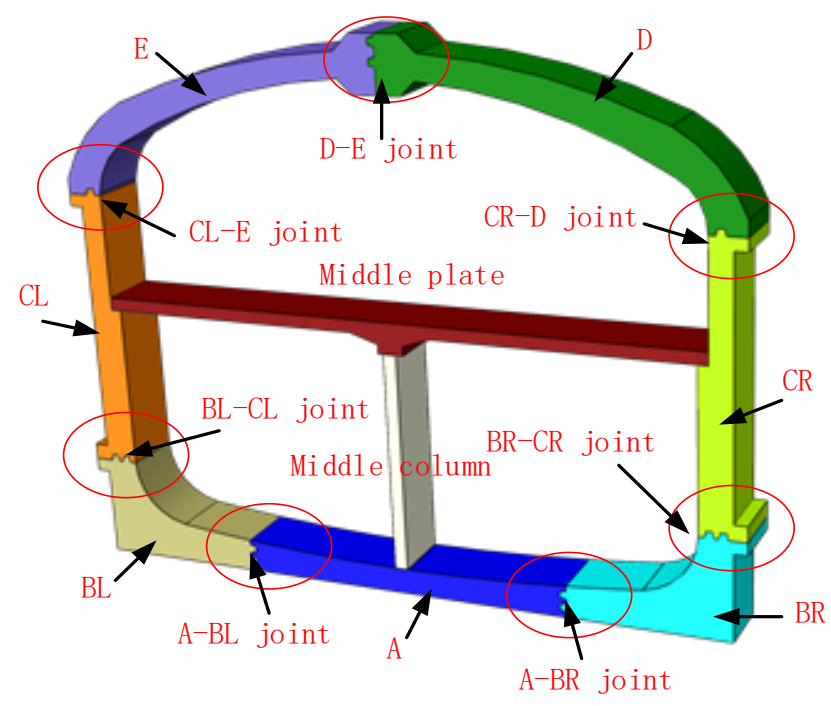

Figure 5. Distribution of the prefabricated components.

The hexahedral C3D8R (three-dimensional eight-node hexahedron reduced integration) element was used in the finite model of structure and soil. The thickness of the fabricated station structure was $2 \mathrm{~m}$, and the damping ratio of the structure was ignored. According to the position and size of the station in the soil, the depth of the intercepted soil model was $60 \mathrm{~m}$, the width of the soil was more than three times that of the station structure, and the width of the intercepted soil model was $150 \mathrm{~m}$. In order to ensure calculation accuracy and efficiency, the mesh size of the soil and structure should meet the requirements:

$$
\Delta X_{\max }=(1 / 6 \sim 1 / 8) c_{\min } / f_{\max }
$$

where $\Delta X_{\max }$ is the maximum size of the grid, $c_{\min }$ is the minimum shear wave velocity, and $f_{\max }$ is the dominant frequency of the input seismic wave.

According to soil's physical and mechanical parameters, the minimum shear wave velocity was $115 \mathrm{~m} / \mathrm{s}$, the maximum dominant frequency of input seismic wave was $3 \mathrm{~Hz}$, and the maximum mesh size should be less than 4.8-6.4 m. According to previous research experience and computer performance, the size of the structure grid was $0.2 \mathrm{~m}$, and the size of the soil grid was $0.5-2 \mathrm{~m}$.

\subsection{Contact Characteristics}

The contact properties between the soil and the underground structure are not negligible when studying the seismic response of underground structures and are also widely used in the analysis of underground structures [39-41]. More importantly, the prefabricated components of the fabricated station structure adopt dry-type connection joints, as shown in Figure 6. The normal contact of prefabricated components adopts a "hard" contact, and the tangential contact adopts the Coulomb friction criterion. 


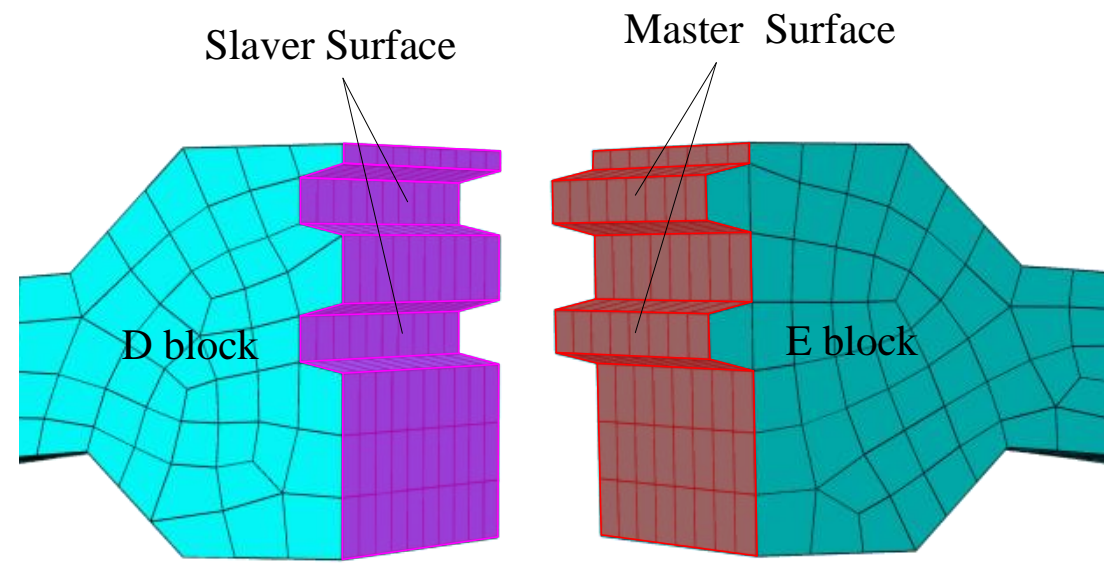

Figure 6. Contact simulation of prefabricated components (take the D-E joint as an example).

According to Equation (6), when the tangential shear stress is greater than the critical shear stress of the contact interface, the contact surface will undergo relative sliding deformation:

$$
\tau_{\text {crit }}=\mu \cdot P_{\text {crit }}
$$

where $P_{\text {crit }}$ is the normal contact stress of the contact surface and $\mu$ is the friction coefficient of the contact surface, which is $0.2[29,30,42]$ for the contact surface of the prefabricated components and 0.4 [43] for the contact surface of the structure and soil.

In order to ensure the accuracy of the boundary conditions and ground motion input, a three-dimensional viscoelastic artificial boundary was applied to the boundary of the soil finite element model, except for the top boundary. Based on such a modeling method, the finite element model is shown in Figure 7.

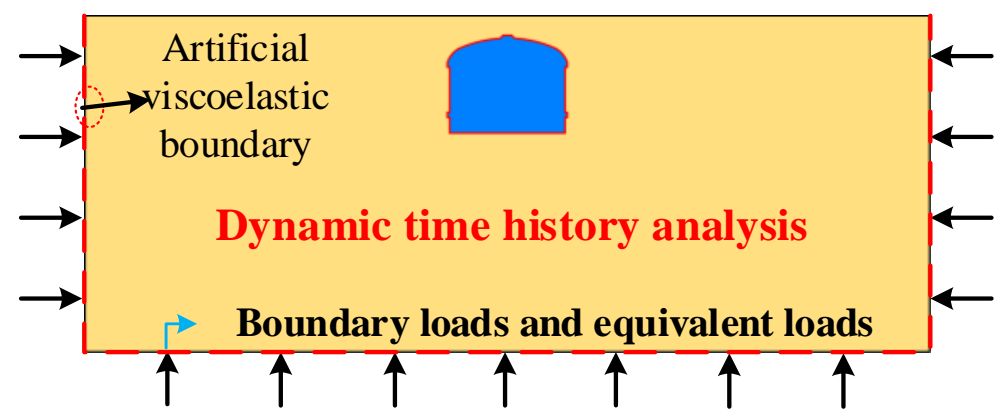

Figure 7. The numerical model with a viscoelastic boundary.

\subsection{The Constitutive Model Introduction of the Structure and Soil}

(1) Constitutive model of the soil

Since this research focused on the dynamic characteristics of underground structures, the equivalent linearization method [44] was adopted to consider the nonlinear behavior of soil under strong earthquakes. The same method was applied and verified by relevant studies $[45,46]$. Rayleigh damping was used to simulate the hysteresis characteristics and nonlinear characteristics of the soil under dynamic cyclic loading, and the damping matrix is shown in Equation (7), where $\alpha_{0}$ and $\alpha_{1}$ are the damping proportionality coefficients, $\zeta$ is the damping ratio ( $5 \%$ in this study), $\omega_{i}$ is the ith order natural frequency of the soil layer, and $\omega_{j}$ is the maximum Fourier amplitude for the input ground motion. Related applications and validation are in $[47,48]$.

$$
\begin{gathered}
{[C]=\alpha_{0}[M]+\alpha_{1}[K]} \\
\left\{\begin{array}{c}
\alpha_{0} \\
\alpha_{1}
\end{array}\right\}=\frac{2 \xi}{\omega_{i}+\omega_{j}}\left\{\begin{array}{c}
\omega_{i} \omega_{j} \\
1
\end{array}\right\} .
\end{gathered}
$$


(2) Constitutive model of the concrete

Concrete damage plastic (CDP) material is a material in the ABAQUS material library, which is used to describe the deformation behavior and strength characteristics of concrete. The CDP model is typical and widely used in the literature [19,39], and its stress-strain curve can be described using the damage factor and plastic strain. The CDP model parameters of the prefabricated components are shown in Table 3.

Table 3. Plastic damage model parameters of prefabricated components.

\begin{tabular}{cc}
\hline Parameter & Value \\
\hline Density $\left(\mathrm{kg} / \mathrm{m}^{3}\right)$ & 2500 \\
Elastic modulus $(\mathrm{GPa})$ & 34.5 \\
Poisson's ratio & 0.25 \\
Dilation angle $(\theta)$ & 30 \\
Compression stiffness recovery parameter & 1.0 \\
Tensile stiffness recovery parameter & 0.0 \\
\hline
\end{tabular}

\subsection{Ground Motion Input}

According to the soil characteristics of the site where the station is located, three real seismic waves from the PEER (Pacific Earthquake Engineering Research Center) were selected as the input ground motions, namely, the Parkfield wave, Kobe wave, and Taft wave. Usually, the peak acceleration of the vertical component is half to two-thirds of the peak acceleration of the horizontal component [39]. The peak accelerations of different horizontal components $(0.1 \mathrm{~g}, 0.2 \mathrm{~g}, 0.3 \mathrm{~g})$ and seismic excitations in different directions were considered. The peak acceleration of the vertical component was two-thirds that of the horizontal component. The recorded seismic wave time history and Fourier spectrum are shown in Figure 8.
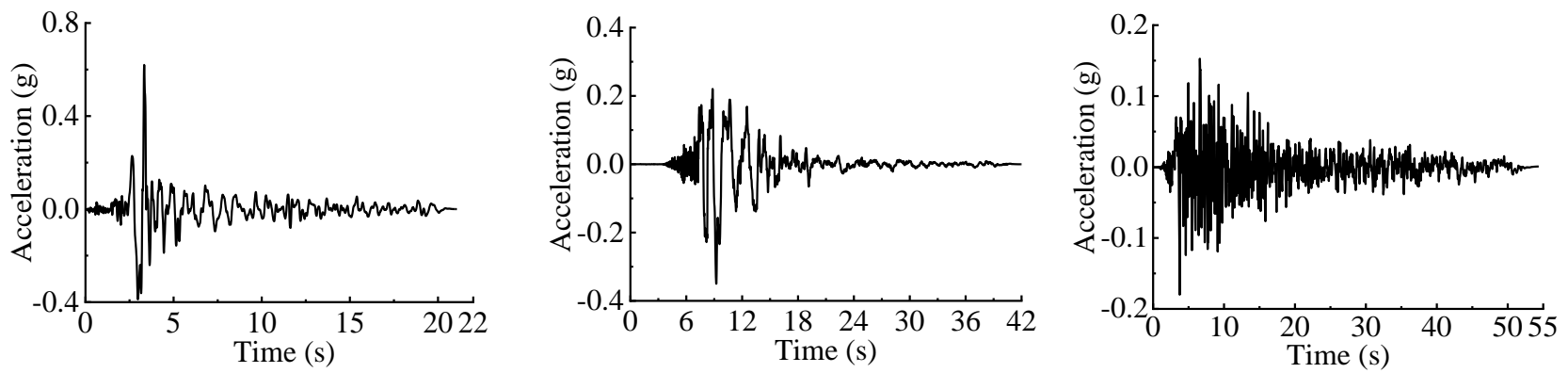

(a) Acceleration history of Parkfield (b) Acceleration history of Kobe

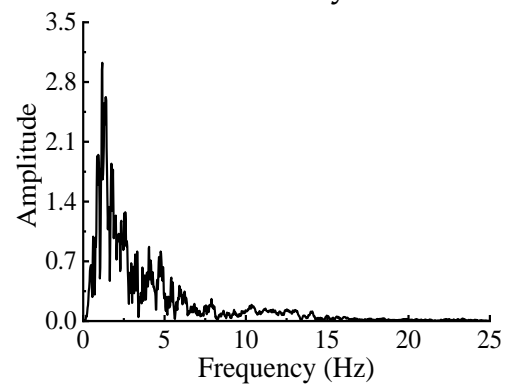

(d) Fourier spectrum of Parkfield

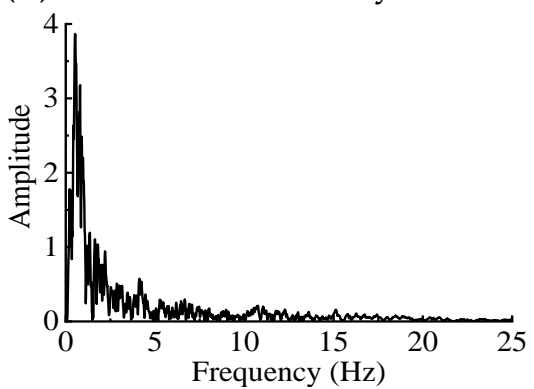

(e) Fourier spectrum of Kobe (c) Acceleration history of Taft

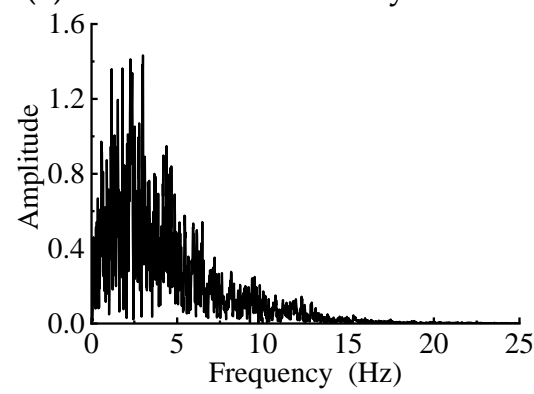

(f) Fourier spectrum of Taft

Figure 8. Acceleration time histories and Fourier spectra of the seismic waves.

In EERA software, the equivalent linearization method was used to calculate the equivalent shear modulus and damping ratio by calculating the $G_{\max } / G$-shear strain and damping ratio-shear strain relationship of soil, which were used in the dynamic time history analysis of the numerical model. Figure 9 shows the equivalent linearization param- 
eters of soil under different seismic motions. Figure 10 shows the equivalent linearization parameters of soil under different seismic intensities.
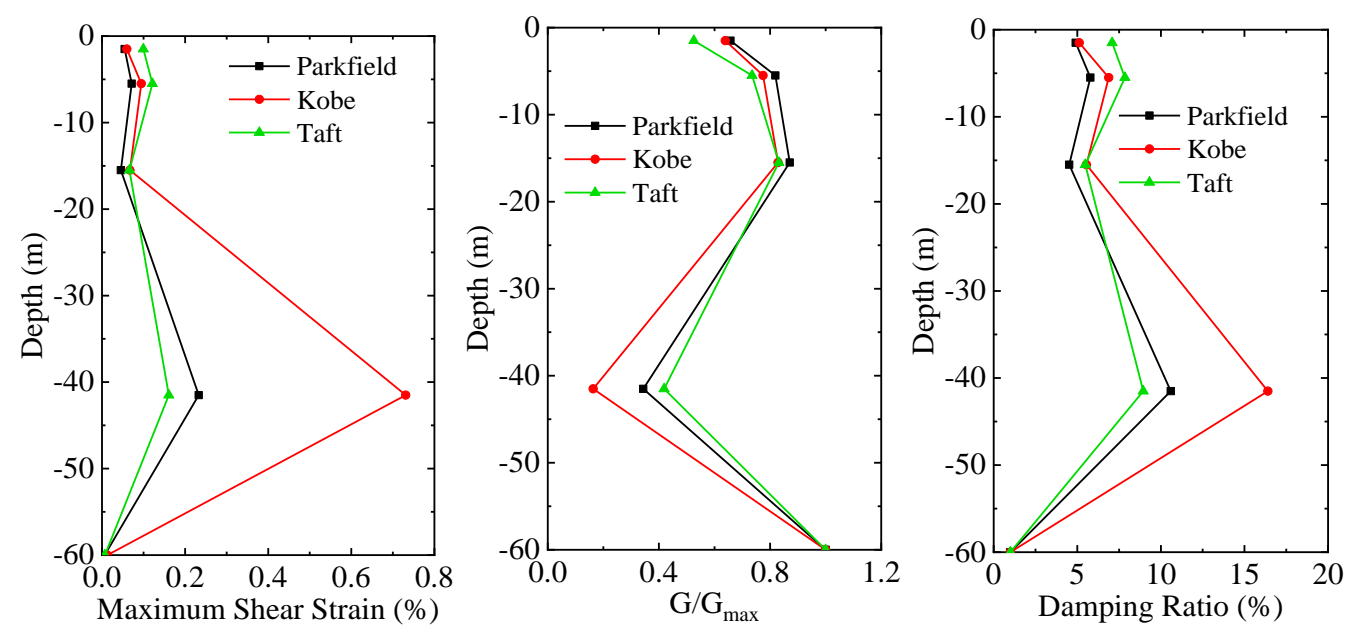

Figure 9. Equivalent linearization parameters (peak acceleration $=0.3 \mathrm{~g}$ ).
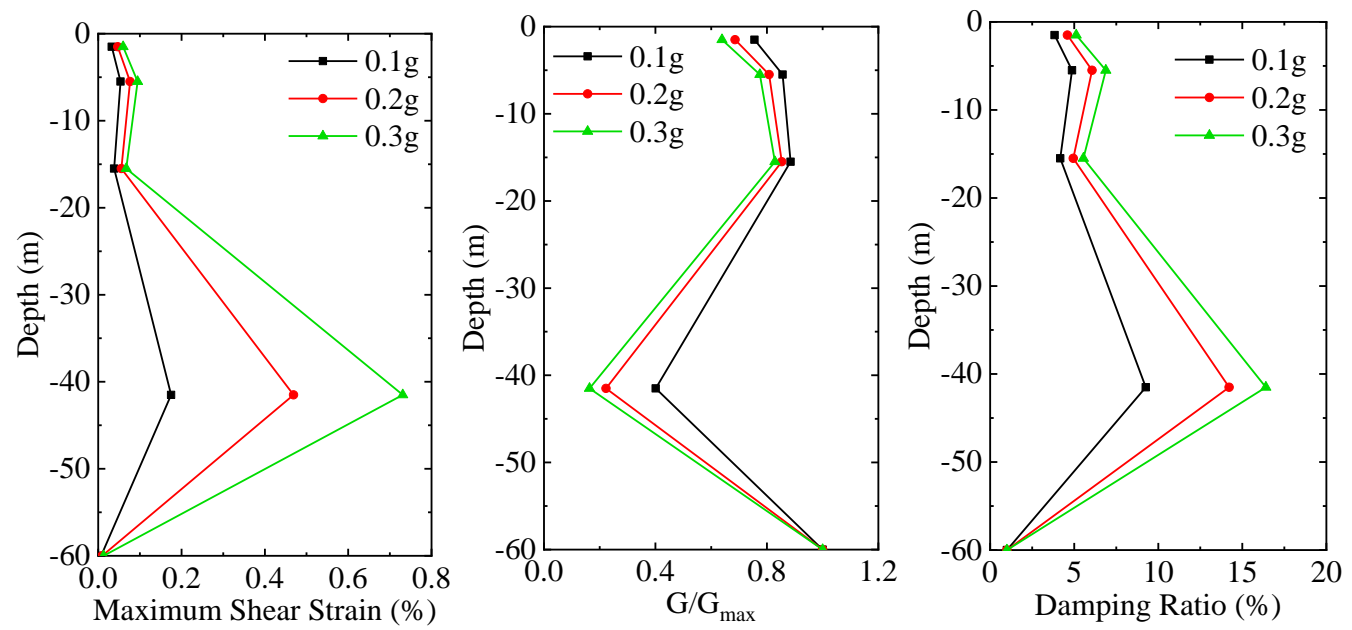

Figure 10. Equivalent linearization parameters (taking the Kobe wave as an example).

Under the action of seismic waves with the same peak seismic acceleration, the frequency of the seismic waves had a greater effect on the maximum shear strain of the soil, which also showed the necessity of using different seismic waves for the seismic analysis of underground structures. As the peak acceleration of the seismic wave increased, the maximum shear strain of the soil increased, but it was not linearly related. Therefore, the seismic peak acceleration and the seismic response of the underground structure were also not linearly related.

\section{Numerical Results}

In order to compare the seismic responses of the fabricated subway stations with different joint distributions, the mechanical and deformation characteristics, such as plastic strain, interlayer relative deformation, and internal force, under different ground motion records (Parkfield wave, Kobe wave, and Taft wave), different seismic intensities ( $0.1 \mathrm{~g}$, $0.2 \mathrm{~g}, 0.3 \mathrm{~g})$, and different earthquake conditions $(\mathrm{H}, \mathrm{HV})$ were studied. The model named CC-Parkfield- $0.3 \mathrm{~g}-\mathrm{H}$ represents the seismic response of Yuanjiadian station in Changchun under the horizontal component of Parkfield wave with the peak acceleration of $0.3 \mathrm{~g}$. HV represents the coupling effect of horizontal and vertical components. 


\subsection{Different Ground Motion Records}

The deformation and mechanical characteristics of single-arch large-span fabricated station structures with different joint distributions were analyzed under different ground motions. The peak acceleration of the horizontal seismic component of $0.3 \mathrm{~g}$ was taken for the rest of Section 4.1.

\subsubsection{Plastic Strain}

Compared with the cast-in-place station structure, the fabricated station structure is connected by dry-type joints and has less tensile damage. The compression damage of concrete can be used as the evaluation index of the seismic response of the fabricated station structure. The CDP model defines the compression damage to measure the structure's compression failure state with a variation range of $0-1$, corresponding to the compression plastic strain in ABAQUS. When the compressive plastic strain value is 0 , the structure has no compressive damage. A value of 1 means the structure is completely destroyed. Figure 11 shows the plastic strain cloud of the fabricated subway station structure with different joint locations. Table 4 shows the maximum plastic strain of fabricated station structures with the different joint distributions. The plastic strain mainly occurred at the B-C joint and C-D/E joint of the sidewall, and block B under different ground motion excitations. The maximum plastic strains of the CC model, QD model, and SZ model were $0.0143,0.0141$, and 0.0145 , respectively. The maximum impact rate of the vault or bottom plate joints on the structural failure was $3.2 \%$. Under the action of an earthquake, the underground structure deforms under the constraint of the surrounding soil. The most serious damage in the prefabricated structures lay in the B-C joints. The joints of the vault and the bottom plate were always in the extrusion state, as in the cast-in-place structure. Therefore, the joint changes of the vault and bottom plate had little influence on the plastic strain of the structure.
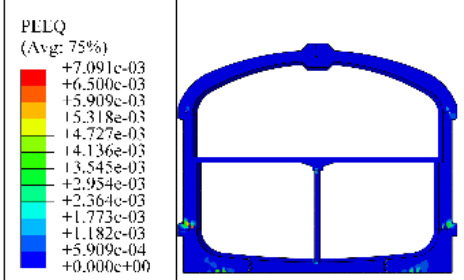

CC-Parkfield-0.3 g-H

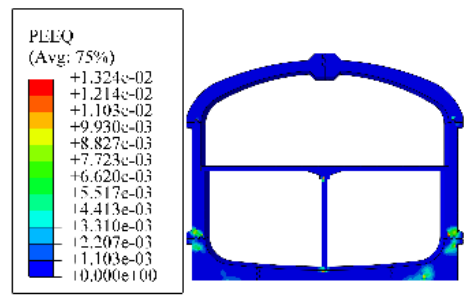

CC-Kobe- $0.3 \mathrm{~g}-\mathrm{H}$
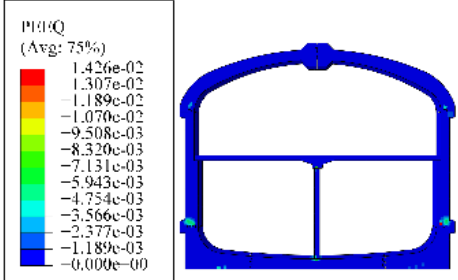

CC-Taft-0.3 g-H
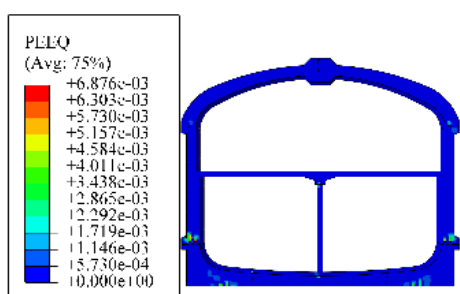

QD-Parkfield-0.3 g-H

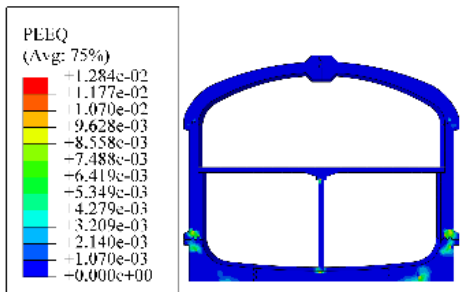

QD-Kobe-0.3 g-H

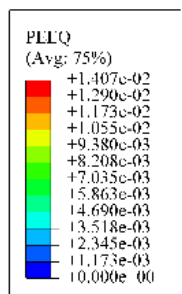

QD-Taft-0.3 g-H

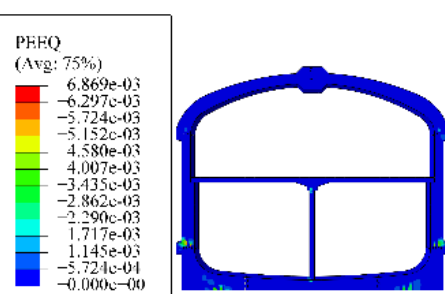

SZ-Parkfield-0.3 g-H

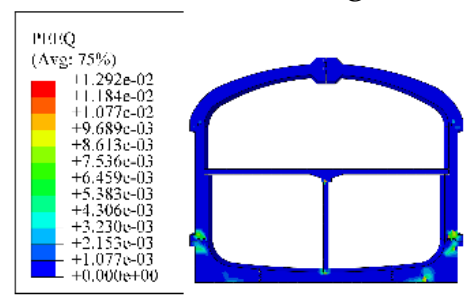

SZ-Kobe- 0.3 g-H

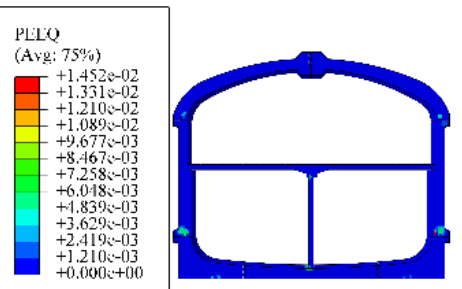

SZ-Taft-0.3 g-H

Figure 11. The cloud diagrams of the plastic strains. 
Table 4. Maximum plastic strains $\left(\times 10^{-3}\right)$.

\begin{tabular}{ccccccc}
\hline & & & & \multicolumn{3}{c}{ Impact Rate (\%) } \\
\cline { 5 - 7 } $\begin{array}{c}\text { Seismic } \\
\text { Waves }\end{array}$ & CC & QD & SZ & $\begin{array}{c}\text { QD } \\
\text { Compared } \\
\text { with CC }\end{array}$ & $\begin{array}{c}\text { SZ } \\
\text { Compared } \\
\text { with QD }\end{array}$ & $\begin{array}{c}\text { Sompared } \\
\text { with CC }\end{array}$ \\
\hline $\begin{array}{c}\text { Parkfield } \\
\text { Kobe }\end{array}$ & 7.091 & 6.876 & 6.869 & $-3.03 \%$ & $-0.10 \%$ & $-3.13 \%$ \\
Taft & 13.24 & 12.84 & 12.92 & $-3.02 \%$ & $0.62 \%$ & $-2.42 \%$ \\
\hline
\end{tabular}

\subsubsection{Deformation Analysis}

Figure 12 shows the time history of the relative deformation between the vault and the bottom plate of the fabricated station structure (interlayer relative deformation). Table 5 shows the maximum interlayer relative deformation of the fabricated station structures with the different joint distributions. Under the excitation of different ground motions, the maximum interlayer relative deformations of the CC model, QD model, and SZ model reached $87.03 \mathrm{~mm}, 87.03 \mathrm{~mm}$, and $87.11 \mathrm{~m}$, respectively. The maximum influence rate of the vault or bottom plate joints on the interlayer relative deformation was only $0.7 \%$. The deformation of the structure depended on the constraint of the soil and mainly the characteristics of the seismic waves. Under the same ground motion, the interlayer relative deformation of the fabricated station structure was almost the same; therefore, the distribution form of the joints could be ignored.

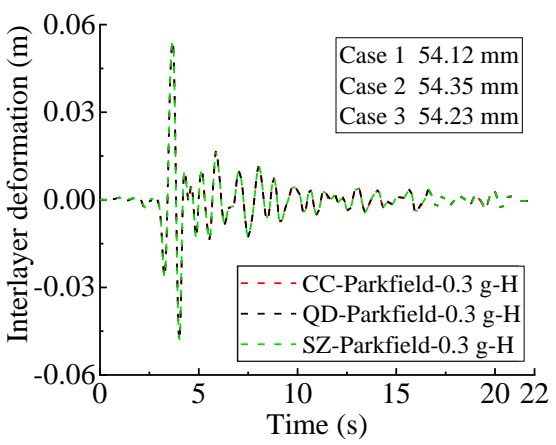

Parkfield-0.3 g-H

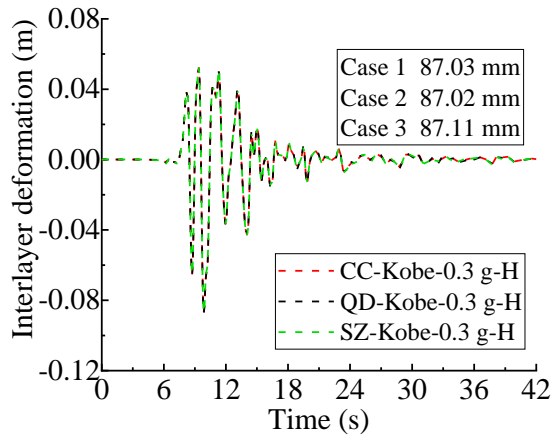

Kobe- 0.3 g-H

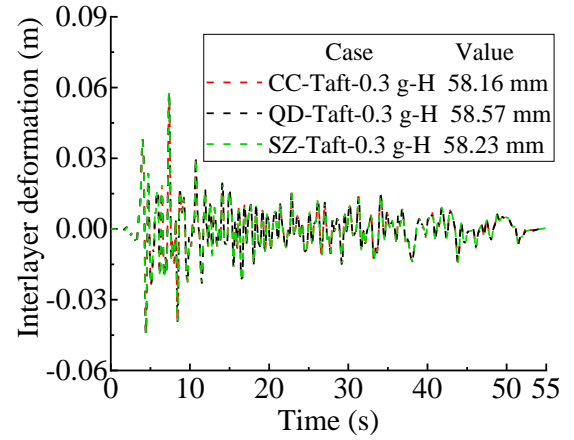

Taft-0.3 g-H

Figure 12. The time histories of interlayer relative deformations.

Table 5. Maximum interlayer relative deformations of the structure (mm).

\begin{tabular}{ccccccc}
\hline & & & & \multicolumn{3}{c}{ Impact Rate (\%) } \\
\cline { 5 - 7 } $\begin{array}{c}\text { Seismic } \\
\text { Waves }\end{array}$ & CC & QD & SZ & $\begin{array}{c}\text { QD } \\
\text { Compared } \\
\text { with CC }\end{array}$ & $\begin{array}{c}\text { SZ } \\
\text { Compared } \\
\text { with QD }\end{array}$ & $\begin{array}{c}\text { SZ } \\
\text { Compared } \\
\text { with CC }\end{array}$ \\
\hline $\begin{array}{c}\text { Parkfield } \\
\text { Kobe }\end{array}$ & 54.12 & 54.35 & 54.23 & $0.42 \%$ & $-0.22 \%$ & $0.20 \%$ \\
Taft & 87.03 & 87.03 & 87.11 & $0.00 \%$ & $0.09 \%$ & $0.09 \%$ \\
\hline
\end{tabular}

\subsubsection{Internal Force}

In addition to deformation and plastic strain, the internal force at the joints of the fabricated station structure is also an important index to study seismic performance. Figure 13 shows the maximum internal force distribution at the joint positions of the fabricated station structure. 

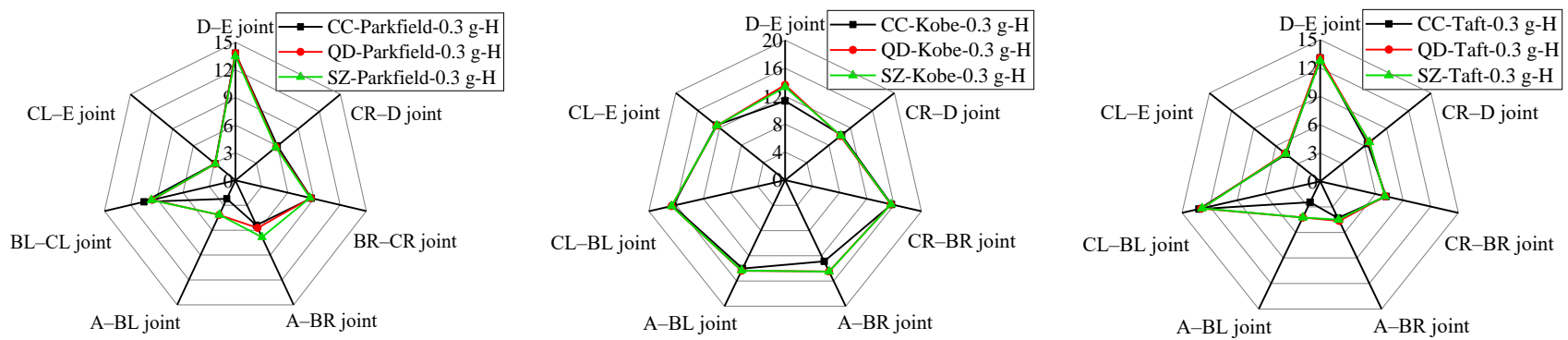

(a) Maximum axial force distributions under different seismic waves (unit: $10^{6} \mathrm{~N}$ )
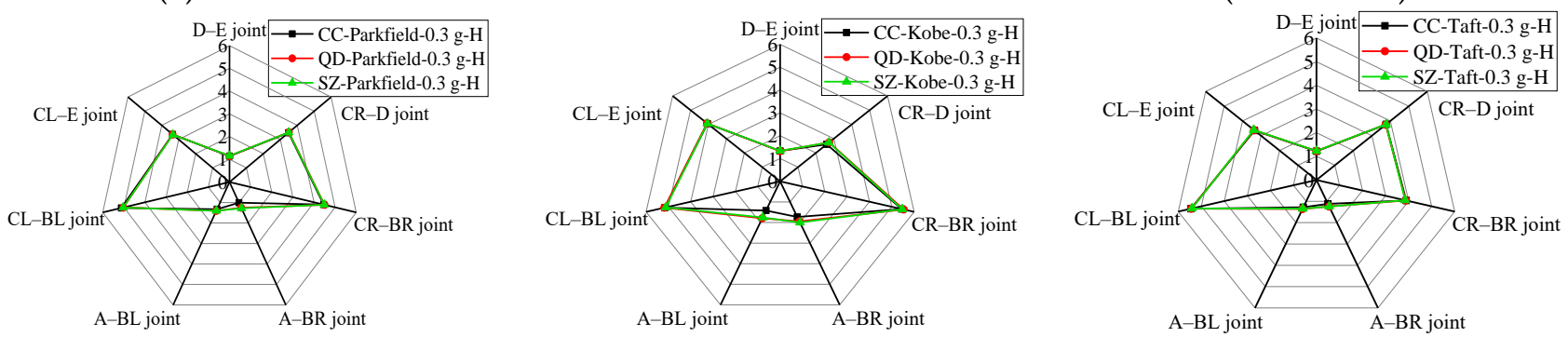

(b) Maximum shear force distributions under different seismic waves (unit: $10^{6} \mathrm{~N}$ )
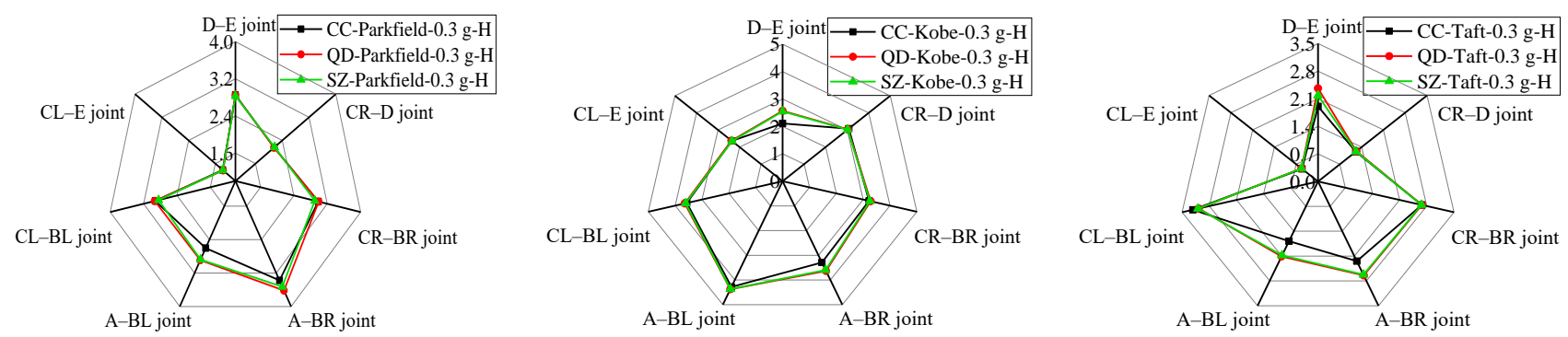

(c) Maximum bending moment distributions under different seismic waves (unit: $10^{6} \mathrm{~N} \cdot \mathrm{m}$ )

Figure 13. The maximum internal force distributions at the joints.

Tables 6-8 show the maximum internal force of the fabricated station structures with the different joint distributions. According to the joint locations of Changchun Metro Station, the maximum internal forces at seven joints were extracted. The maximum internal force and distribution pattern of the CC model, QD model, and SZ model were basically the same. The maximum influence rates of the axial force, shear force, and bending moment were $2.39 \%, 1.93 \%$, and $6.83 \%$, respectively. The joint distribution position had little influence on the internal force of the fabricated station structure. The internal force difference of the fabricated station structure with different joints was mainly concentrated in the position of the vault and bottom plate, especially the axial force and bending moment. The whole assembly method of the vault and bottom plate was adopted without connection joints. Since the joints undergo coordinated deformation, the internal force of the prefabricated component without joints is greater than or equal to that with joints, which is consistent with the conclusion obtained from the comparative analysis of the internal force of cast-in-place and fabricated station structures in relevant studies [31,49].

Table 6. Maximum axial forces $\left(\times 10^{3} \mathrm{kN}\right)$.

\begin{tabular}{ccccccc}
\hline & & & & \multicolumn{3}{c}{ Impact Rate (\%) } \\
\cline { 5 - 7 } $\begin{array}{c}\text { Seismic } \\
\text { Waves }\end{array}$ & CC & QD & SZ & $\begin{array}{c}\text { QD } \\
\text { Compared } \\
\text { with CC }\end{array}$ & $\begin{array}{c}\text { SZ } \\
\text { Compared } \\
\text { with QD }\end{array}$ & $\begin{array}{c}\text { Sompared } \\
\text { with CC }\end{array}$ \\
\hline $\begin{array}{c}\text { Parkfield } \\
\text { Kobe }\end{array}$ & 13.82 & 13.82 & 13.49 & $0.00 \%$ & $-2.39 \%$ & $-2.39 \%$ \\
Taft & 15.18 & 15.33 & 15.34 & $0.99 \%$ & $0.07 \%$ & $1.05 \%$ \\
\hline
\end{tabular}


Table 7. Maximum shear forces $\left(\times 10^{3} \mathrm{kN}\right)$.

\begin{tabular}{ccccccc}
\hline \multirow{2}{*}{$\begin{array}{c}\text { Seismic } \\
\text { Waves }\end{array}$} & CC & QD & SZ & $\begin{array}{c}\text { QD } \\
\text { Compared } \\
\text { with CC }\end{array}$ & $\begin{array}{c}\text { Impact Rate (\%) } \\
\text { Compared } \\
\text { with QD }\end{array}$ & $\begin{array}{c}\text { SZ } \\
\text { Compared } \\
\text { with CC }\end{array}$ \\
\hline $\begin{array}{c}\text { Parkfield } \\
\text { Kobe }\end{array}$ & 5.12 & 5.02 & 5.04 & $-1.93 \%$ & $0.22 \%$ & $-1.56 \%$ \\
Taft & 5.45 & 5.54 & 5.47 & $1.58 \%$ & $-1.21 \%$ & $0.37 \%$ \\
\hline
\end{tabular}

Table 8. Maximum bending moments $\left(\times 10^{3} \mathrm{kN} \cdot \mathrm{m}\right)$.

\begin{tabular}{ccccccc}
\hline & & & & \multicolumn{3}{c}{ Impact Rate (\%) } \\
\cline { 5 - 7 } $\begin{array}{c}\text { Seismic } \\
\text { Waves }\end{array}$ & CC & QD & SZ & $\begin{array}{c}\text { QD } \\
\text { Compared } \\
\text { with CC }\end{array}$ & $\begin{array}{c}\text { SZ } \\
\text { Compared } \\
\text { with QD }\end{array}$ & $\begin{array}{c}\text { SZ } \\
\text { Compared } \\
\text { with CC }\end{array}$ \\
\hline $\begin{array}{c}\text { Parkfield } \\
\text { Kobe }\end{array}$ & 3.06 & 3.27 & 3.19 & $6.83 \%$ & $-2.39 \%$ & $4.25 \%$ \\
Taft & 3.78 & 3.87 & 3.87 & $2.46 \%$ & $-0.13 \%$ & $2.38 \%$ \\
\hline
\end{tabular}

According to relevant literature, the change in seismic conditions [50-52] and peak acceleration [53-55] of a seismic wave will increase the seismic response of underground structures and, more importantly, will obviously change the seismic response characteristics. In order to further analyze the influence of the joint distribution on the seismic response of the fabricated station structure, the seismic conditions and peak acceleration were analyzed and the results are given in Sections 4.2 and 4.3 according to the research ideas of Section 4.1.

\subsection{Different Seismic Conditions}

The peak accelerations of the horizontal component and vertical component were $0.3 \mathrm{~g}$ and $0.195 \mathrm{~g}$ with Kobe wave.

\subsubsection{Plastic Strain}

Table 9 shows the maximum plastic strain of the fabricated station structures under the coupling effect of horizontal and vertical components. The existence of vertical ground motion increased the seismic load of the overburden of the underground structure, and thus increased the axial force of $\mathrm{B}-\mathrm{C}$ joint, resulting in the increase in the plastic strain of the B-C joint. The maximum plastic strains of the CC model, QD model, and SZ model reached $0.0217,0.0219$, and 0.0213 , respectively, under the coupled seismic action. Compared with the horizontal seismic action, the plastic strain of the BR-CR joints on the sidewall increases obviously. The maximum impact rate of the vault or bottom plate joints on the structural failure was $3.05 \%$.

Table 9. Maximum plastic strains $\left(\times 10^{-3}\right)$.

\begin{tabular}{ccccccc}
\hline \multirow{2}{*}{$\begin{array}{c}\text { Seismic } \\
\text { Waves }\end{array}$} & CC & QD & SZ & $\begin{array}{c}\text { QD } \\
\text { Compared } \\
\text { with CC }\end{array}$ & $\begin{array}{c}\text { Impact Rate (\%) } \\
\text { Compared } \\
\text { with QD }\end{array}$ & $\begin{array}{c}\text { SZ } \\
\text { Compared } \\
\text { with CC }\end{array}$ \\
\hline Kobe & 21.67 & 21.95 & 21.28 & $1.29 \%$ & $-3.05 \%$ & $-1.80 \%$ \\
\hline
\end{tabular}




\subsubsection{Deformation Analysis}

Table 10 shows the maximum interlayer relative deformation of fabricated station structures under the coupling effect of horizontal and vertical components. The time history of the interlayer relative deformation was consistent with that of the horizontal seismic component under the coupling effect of the ground motion. The vertical seismic component increased the maximum interlayer relative deformations of the CC model, QD model, and SZ model by $0.12 \%, 0.29 \%$, and $0.2 \%$, respectively. The maximum influence rate of the vault or bottom plate joints on the interlayer relative deformation was $0.17 \%$. The joint distributions had little influence on the interlayer relative deformation of the prefabricated station structure.

Table 10. Maximum interlayer relative deformations of the structures ( $\mathrm{mm})$.

\begin{tabular}{ccccccc}
\hline \multirow{2}{*}{$\begin{array}{c}\text { Seismic } \\
\text { Waves }\end{array}$} & CC & QD & SZ & $\begin{array}{c}\text { QD } \\
\text { Compared } \\
\text { with CC }\end{array}$ & $\begin{array}{c}\text { SZ } \\
\text { Compared } \\
\text { with QD }\end{array}$ & $\begin{array}{c}\text { SZ } \\
\text { Compared } \\
\text { with CC }\end{array}$ \\
\hline Kobe & 87.13 & 87.28 & 87.28 & $0.17 \%$ & 0 & $0.17 \%$ \\
\hline
\end{tabular}

\subsubsection{Internal Force}

Table 11 shows the maximum internal force of the fabricated station structures under the coupling effect of the horizontal and vertical components.

Table 11. Maximum internal forces.

\begin{tabular}{ccccccc}
\hline & & & & \multicolumn{3}{c}{ Impact Rate (\%) } \\
\cline { 5 - 7 } $\begin{array}{c}\text { Maximum Internal } \\
\text { Force }\end{array}$ & CC & QD & SZ & $\begin{array}{c}\text { QD } \\
\text { Compared } \\
\text { with CC }\end{array}$ & $\begin{array}{c}\text { SZ } \\
\text { Compared } \\
\text { with QD }\end{array}$ & $\begin{array}{c}\text { SZ } \\
\text { Compared } \\
\text { with CC }\end{array}$ \\
\hline Axial force $\left(\times 10^{3} \mathrm{kN}\right)$ & 18.60 & 18.59 & 18.75 & $-0.05 \%$ & $0.86 \%$ & $0.81 \%$ \\
$\begin{array}{c}\text { Shear force }\left(\times 10^{3} \mathrm{kN}\right) \\
\text { Bending moment } \\
\left(\times 10^{3} \mathrm{kN} \cdot \mathrm{m}\right)\end{array}$ & 5.17 & 5.20 & 5.20 & $0.43 \%$ & $0.00 \%$ & $0.58 \%$ \\
\hline
\end{tabular}

The maximum impact rates of the vault or bottom plate joints on the axial force, shear force, and bending moment were $0.86 \%, 0.43 \%$, and $4.62 \%$, respectively, indicating that the vertical seismic component had little influence on the joint distribution of the fabricated station structure.

The overburden load increased by the vertical seismic component could hardly overcome the axial resistance moment of the vault and the bottom plate caused by the horizontal seismic component. Under the coupling effect of the horizontal and vertical seismic components, the seismic response characteristics of the fabricated station structure with different joint distributions did not change significantly, which was consistent with the horizontal component.

\subsection{Different Seismic Intensities}

Peak accelerations of $0.1 \mathrm{~g}, 0.2 \mathrm{~g}$, and $0.3 \mathrm{~g}$ of the Kobe wave were used to analyze the effect of peak acceleration of ground motion.

\subsubsection{Plastic Strain}

Table 12 shows the maximum plastic strain of the fabricated station structures under the different seismic intensities. The plastic strain of the fabricated station structure increased monotonically with the increase in the seismic peak acceleration. When the peak accelerations of seismic waves were $0.1 \mathrm{~g}, 0.2 \mathrm{~g}$, and $0.3 \mathrm{~g}$, the maximum impact rates of 
the vault or bottom plate joints on the structural failure were $4.74 \%, 11.26 \%$, and 3.02\%, respectively. The ground motion intensity negligibly affected the maximum plastic strain of fabricated station structures with different joint distributions.

Table 12. Maximum plastic strains $\left(\times 10^{-3}\right)$.

\begin{tabular}{ccccccc}
\hline & & & & \multicolumn{3}{c}{ Impact Rate (\%) } \\
\cline { 5 - 7 } $\begin{array}{c}\text { Peak } \\
\text { Acceleration }\end{array}$ & CC & QD & SZ & $\begin{array}{c}\text { QD } \\
\text { Compared } \\
\text { with CC }\end{array}$ & $\begin{array}{c}\text { SZ } \\
\text { Compared } \\
\text { with QD }\end{array}$ & $\begin{array}{c}\text { SZ } \\
\text { Compared } \\
\text { with CC }\end{array}$ \\
\hline $0.1 \mathrm{~g}$ & 2.152 & 2.254 & 2.179 & $4.74 \%$ & $-3.33 \%$ & $1.25 \%$ \\
$0.2 \mathrm{~g}$ & 7.561 & 8.084 & 8.412 & $6.92 \%$ & $4.06 \%$ & $11.26 \%$ \\
$0.3 \mathrm{~g}$ & 13.24 & 12.84 & 12.92 & $-3.02 \%$ & $0.62 \%$ & $-2.42 \%$ \\
\hline
\end{tabular}

Compared with that of $0.1 \mathrm{~g}$ and $0.3 \mathrm{~g}$, the maximum plastic strain of the SZ model increased significantly with the peak acceleration of $0.2 \mathrm{~g}$. The dominant frequency of the Kobe wave was very close to that of the SZ model system when the peak acceleration was $0.2 \mathrm{~g}$, and the resonance resulted in a severe seismic response of the soil-structure system.

\subsubsection{Deformation Analysis}

Table 13 shows the maximum interlayer relative deformation of the fabricated station structures with different seismic intensities. The maximum interlayer relative deformation of the fabricated station structure increased monotonically with the increase in seismic peak acceleration. The maximum impact rates of the vault or bottom plate joints on structural failure were $0.92 \%, 0.13 \%$, and $0.09 \%$ under the seismic peak accelerations of $0.1 \mathrm{~g}, 0.2 \mathrm{~g}$, and $0.3 \mathrm{~g}$, respectively. The effect of the seismic intensity on the interlayer relative deformation could be ignored.

Table 13. Maximum interlayer relative deformations of the structures (mm).

\begin{tabular}{ccccccc}
\hline & & & & \multicolumn{3}{c}{ Impact Rate (\%) } \\
\cline { 5 - 7 } $\begin{array}{c}\text { Peak } \\
\text { Acceleration }\end{array}$ & CC & QD & SZ & $\begin{array}{c}\text { QD } \\
\text { Compared } \\
\text { with CC }\end{array}$ & $\begin{array}{c}\text { SZ } \\
\text { Compared } \\
\text { with QD }\end{array}$ & $\begin{array}{c}\text { SZ } \\
\text { Compared } \\
\text { with CC }\end{array}$ \\
\hline $0.1 \mathrm{~g}$ & 25.10 & 24.89 & 24.87 & $-0.84 \%$ & $-0.08 \%$ & $-0.92 \%$ \\
$0.2 \mathrm{~g}$ & 53.82 & 53.78 & 53.75 & $-0.07 \%$ & $-0.06 \%$ & $-0.13 \%$ \\
$0.3 \mathrm{~g}$ & 87.03 & 87.03 & 87.11 & $0.00 \%$ & $0.09 \%$ & $0.09 \%$ \\
\hline
\end{tabular}

\subsubsection{Internal Force}

Tables 14-16 show the maximum internal forces with different seismic intensities. The maximum impact rates of the fully prefabricated vault or bottom plate on the internal force were $5.23 \%, 2.96 \%$, and $2.46 \%$ under the seismic peak accelerations of $0.1 \mathrm{~g}, 0.2 \mathrm{~g}$, and $0.3 \mathrm{~g}$, respectively, indicating that the peak acceleration had little influence on the joint distribution of the fabricated station structure.

Table 14. Maximum axial forces $\left(\times 10^{3} \mathrm{kN}\right)$.

\begin{tabular}{ccccccc}
\hline & & & & \multicolumn{3}{c}{ Impact Rate (\%) } \\
\cline { 5 - 7 } $\begin{array}{c}\text { Peak } \\
\text { Acceleration }\end{array}$ & CC & QD & SZ & $\begin{array}{c}\text { QD } \\
\text { Compared } \\
\text { with CC }\end{array}$ & $\begin{array}{c}\text { SZ } \\
\text { Compared } \\
\text { with QD }\end{array}$ & $\begin{array}{c}\text { SZ } \\
\text { Compared } \\
\text { with CC }\end{array}$ \\
\hline $0.1 \mathrm{~g}$ & 10.92 & 10.75 & 11.05 & $-1.56 \%$ & $2.79 \%$ & $1.19 \%$ \\
$0.2 \mathrm{~g}$ & 14.81 & 14.43 & 14.38 & $-2.57 \%$ & $-0.35 \%$ & $-2.90 \%$ \\
$0.3 \mathrm{~g}$ & 15.18 & 15.33 & 15.34 & $0.99 \%$ & $0.07 \%$ & $1.05 \%$ \\
\hline
\end{tabular}


Table 15. Maximum shear forces $\left(\times 10^{3} \mathrm{kN}\right)$.

\begin{tabular}{ccccccc}
\hline & & & & \multicolumn{3}{c}{ Impact Rate (\%) } \\
\cline { 5 - 7 } $\begin{array}{c}\text { Peak } \\
\text { Acceleration }\end{array}$ & CC & QD & SZ & $\begin{array}{c}\text { QD } \\
\text { Compared } \\
\text { with CC }\end{array}$ & $\begin{array}{c}\text { SZ } \\
\text { Compared } \\
\text { with QD }\end{array}$ & $\begin{array}{c}\text { SZ } \\
\text { Compared } \\
\text { with CC }\end{array}$ \\
\hline $0.1 \mathrm{~g}$ & 3.90 & 3.90 & 3.85 & $0.05 \%$ & $-1.23 \%$ & $-1.28 \%$ \\
$0.2 \mathrm{~g}$ & 5.28 & 5.13 & 5.15 & $-2.80 \%$ & $0.39 \%$ & $-2.46 \%$ \\
$0.3 \mathrm{~g}$ & 5.45 & 5.54 & 5.47 & $1.58 \%$ & $-1.21 \%$ & $0.37 \%$ \\
\hline
\end{tabular}

Table 16. Maximum bending moments $\left(\times 10^{3} \mathrm{kN} \cdot \mathrm{m}\right)$.

\begin{tabular}{ccccccc}
\hline & & & & \multicolumn{3}{c}{ Impact Rate (\%) } \\
\cline { 5 - 7 } $\begin{array}{c}\text { Peak } \\
\text { Acceleration }\end{array}$ & CC & QD & SZ & $\begin{array}{c}\text { QD } \\
\text { Compared } \\
\text { with CC }\end{array}$ & $\begin{array}{c}\text { SZ } \\
\text { Compared } \\
\text { with QD }\end{array}$ & $\begin{array}{c}\text { SZ } \\
\text { Compared } \\
\text { with CC }\end{array}$ \\
\hline $0.1 \mathrm{~g}$ & 2.90 & 2.77 & 2.92 & $-4.38 \%$ & $5.23 \%$ & $0.69 \%$ \\
$0.2 \mathrm{~g}$ & 3.04 & 3.13 & 3.13 & $2.73 \%$ & $-0.03 \%$ & $2.96 \%$ \\
$0.3 \mathrm{~g}$ & 3.78 & 3.87 & 3.87 & $2.46 \%$ & $-0.13 \%$ & $2.38 \%$ \\
\hline
\end{tabular}

With the increase in the peak acceleration, the influence rates of different joint distributions on the seismic response of the fabricated station structure decreased gradually. In other words, with the increase in the seismic intensity, the seismic response of the fabricated station structure with different joint distributions tended to be consistent.

\section{Damage Assessment Method of the Joint}

The damage analysis of fabricated structures can reflect the performance directly and comprehensively and is related to the structure's performance index of deformation, stiffness, and energy. The actual earthquake disaster showed that the failure of concrete structures starts at the material level and then accumulates to cause damage to the parts and the structure, eventually leading to the breakdown of the whole structure [56]. Figure 14 shows the concrete compression damage contour graph at the contact surface of the joint surrounded by the green dashed line.
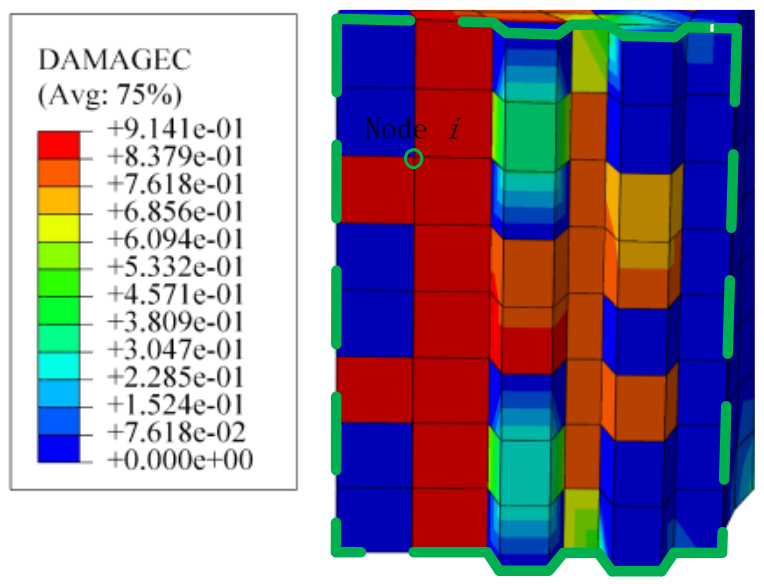

Figure 14. The compression damage contour graphs of the contact surface.

The joint compression damage index $\left(d_{\text {joint,max }}\right)$ is the maximum value of the contact surface's compression damage index between block $\mathrm{S}$ and block M. $d_{\text {joint, } \mathrm{S}} / d_{\text {joint, } \mathrm{M}}$ is defined as the compression damage index of the contact surface between block $\mathrm{S}$ and block $\mathrm{M}$, as shown in Equation (8): 


$$
\begin{gathered}
d_{\text {joint, } \max }=\max \left[d_{\text {joint }, ~}, d_{\text {joint }, \mathrm{M}}\right] \\
d_{\text {joint }}=\sum_{i} \frac{A_{i}}{A} d_{c, i}
\end{gathered}
$$

where $d_{c, i}$ is the compression damage factor of finite element node $i, A_{i}$ is the area of node $i$ within the contact surface, and $A$ is the total area of the contact surface. Compressive damage represents the irreversible compressive damage of concrete ( 0 represents no damage and 1 represents complete damage). According to the CDP model, the joint residual strength index $\left(R_{\text {joint }}\right)$ is shown by Equation (9):

$$
R_{\text {joint }}=\left\{\begin{array}{c}
1 \quad d_{\text {joint }} \leq d_{c} \\
1-d_{\text {joint }} d_{\text {joint }}>d_{c}
\end{array}\right.
$$

where $d_{c}$ is the compression damage factor at the limited compression yield stress, which was taken as 0.173 . The joint completely failed to have load-bearing capacity when the concrete residual strength index reached $90 \%$.

\section{Joints Damage Analysis of Fabricated Structures}

The above research showed that the joint of the vault and bottom plate had little influence on the seismic response of the assembled station structure. However, it is necessary to further study the failure mechanism of the assembly station structure joints under earthquake action. The Kobe wave was used as the input seismic wave and the CC model was taken as the research object. The concrete damage indexes of the finite element nodes on the joint contact surface were obtained based on the ABAQUS finite element software. The compression damage index and the residual strength index were used to describe the compression damage degree and the residual strength of the fabricated structural joints. Figures 13-18 show the histories of the compression damage index and the residual strength index of the fabricated structural joints. In the time history of the joint compression damage index, the time represents the moment the joint damage occurred and the damage ended; in the time history of the residual strength index, the time represents the moment the joint strength degradation happened.

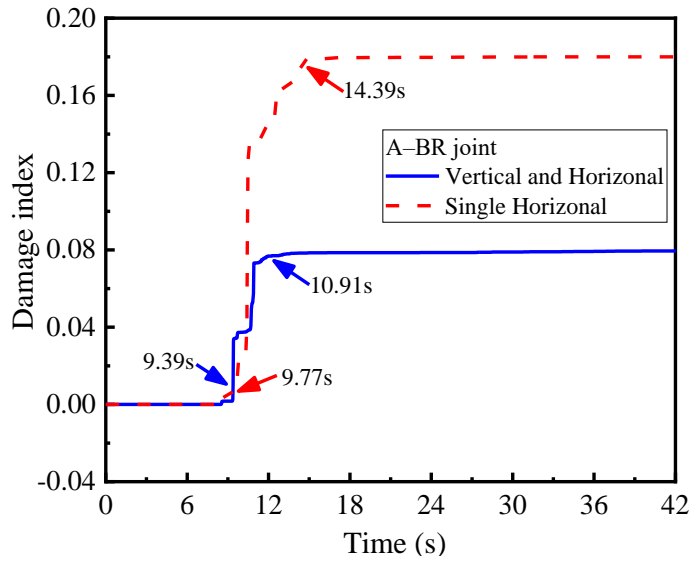

(a) Compression damage time history of the A-BR joints

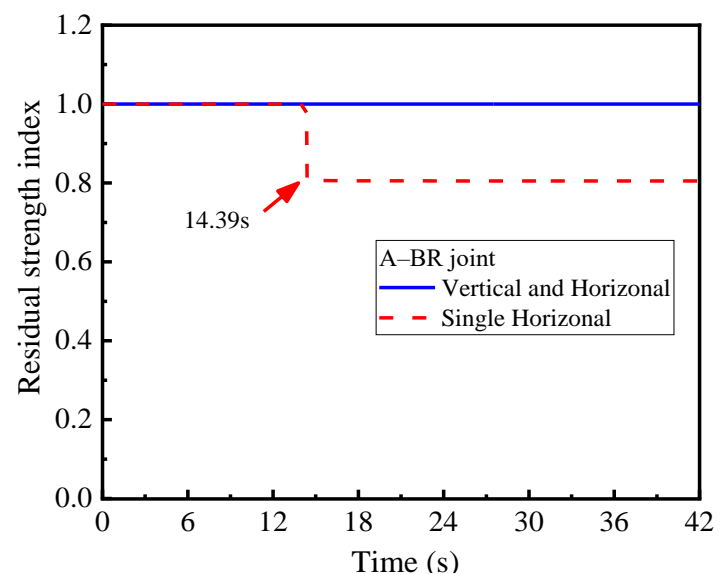

(b) Strength degradation time history of the A-BR joints

Figure 15. Compression damage and strength degradation time history of the A-BR joints. 


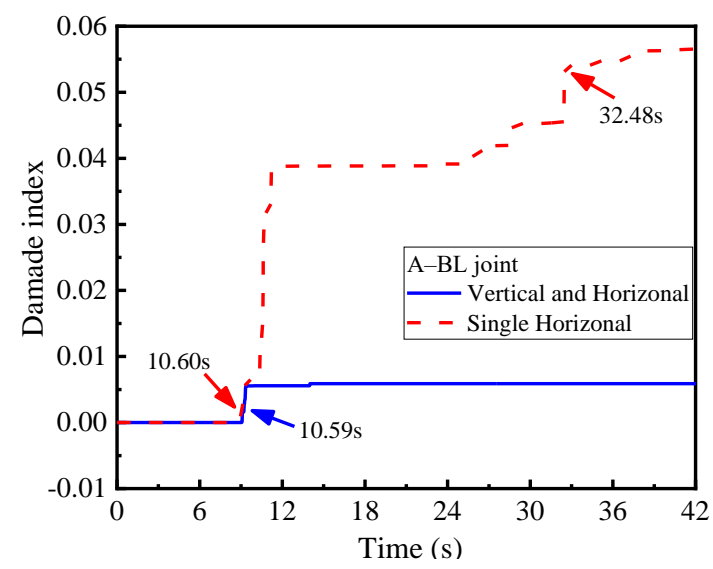

(a) Compression damage time history of the A-BL joints

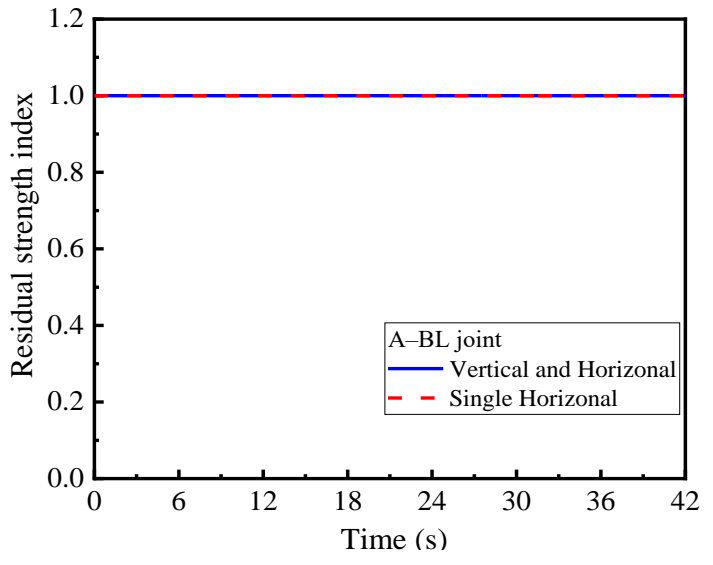

(b) Strength degradation time history of the A-BL joints

Figure 16. Compression damage and strength degradation time history of the A-BL joints.

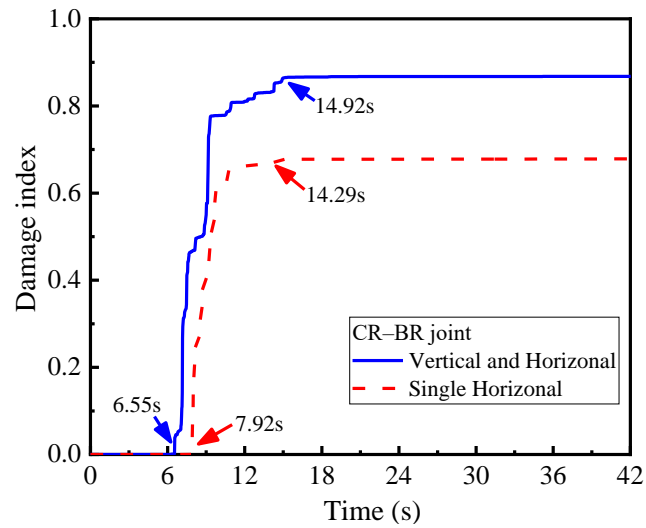

(a) Compression damage time history of the CR-BR joints

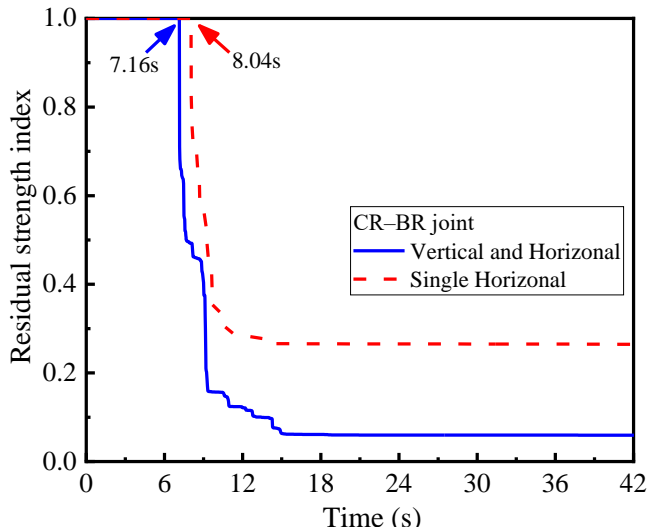

(b) Strength degradation time history of the CR-BR joints

Figure 17. Compression damage and strength degradation time history of the CR-BR joints.

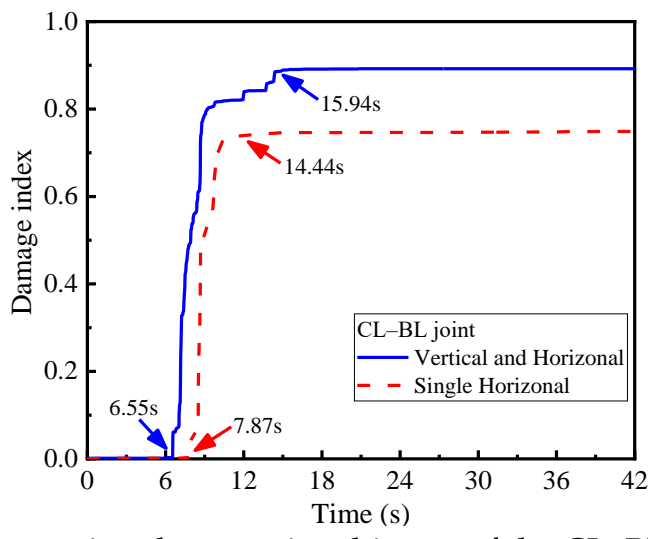

(a) Compression damage time history of the CL-BL joints

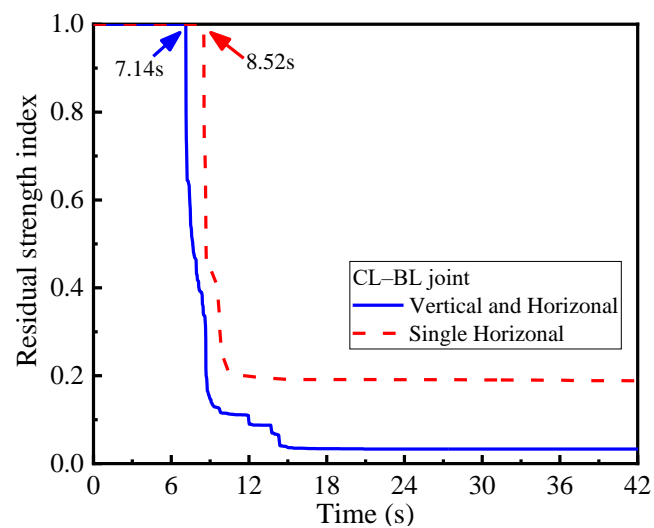

(b) Strength degradation time history of the CL-BL joints

Figure 18. Compression damage and strength degradation time history of the CL-BL joints. 


\subsection{Damage Analysis of $A-B$ Joints}

Figures 15 and 16 show the A-B joint's damage and residual strength histories under different seismic conditions.

The horizontal seismic component mainly caused the compression damage degree in A-B joints. The vertical seismic component had a suppressive effect on the compression damage degree of concrete in A-B joints. The vertical seismic component increased the vertical inertia force of the station overburden, increasing the friction between the bottom plate and the soil layer and inhibiting the compression deformation of the bottom plate. The A-BR joints suffered a slight strength degradation phenomenon, while the bottom plate A-B joints were less affected by the earthquake. The A-B joints were extruded with less damage under seismic action, which was consistent with the conclusions obtained in Section 4.

\subsection{Damage Analysis of $B-C$ Joints}

Figures 17 and 18 show the B-C joint's damage and residual strength histories under different seismic conditions. The initial compressional damage in the $\mathrm{B}-\mathrm{C}$ joints depended mainly on the vertical seismic component. The coupled ground motions damaged the fabricated structure more severe than the horizontal ground motions alone.

The vertical seismic component increased the axial compression ratio of the sidewalls, which made the damage of the joints more severe. The B-C joint received strength degradation under the horizontal ground motion but did not reach the load-bearing capacity. The existence of the vertical seismic component increased the maximum compression damage index of the CR-BR joint by $26 \%$, which finally lost the load capacity and even became damaged. Under the seismic action, the B-C joints were severely damaged and should be reinforced. In the seismic design of underground structures, the presence of vertical seismic components should be considered.

\subsection{Damage Analysis of $C-D / E$ Joints}

Figures 19 and 20 show the damage and residual strength histories of the C-D/E joint under different seismic conditions. The initial damage of the $\mathrm{C}-\mathrm{D} / \mathrm{E}$ joint depended mainly on the vertical seismic excitation, and the final damage state depended on the coupled seismic effect. The strength degradation of the $\mathrm{C}-\mathrm{D} / \mathrm{E}$ joint occurred under different seismic conditions; however, the load-bearing capacity was not dissipated. The CR-D joint and CL-E joint suffered strength degradation under horizontal ground motion, but did not lose its load capacity; the vertical seismic component's existence increased the CL-E joints' compression damage index by $56 \%$, which had a non-negligible effect on the seismic response of the fabricated structure. Both the $\mathrm{C}-\mathrm{D} / \mathrm{E}$ joints and the $\mathrm{B}-\mathrm{C}$ joints are sidewall nodes, but the $\mathrm{C}-\mathrm{D} / \mathrm{E}$ joints had less damage than the $\mathrm{B}-\mathrm{C}$ joints. The vault could provide horizontal forces to restrain the horizontal deformation of the C-D/E node and bear the overburden load. Therefore, the overburden load with a vertical seismic component reduced the horizontal deformation, as well as the damage at the $\mathrm{C}-\mathrm{D} / \mathrm{E}$ joints. The vertical seismic component should be considered in the seismic design of $\mathrm{C}-\mathrm{D} / \mathrm{E}$ joints. 


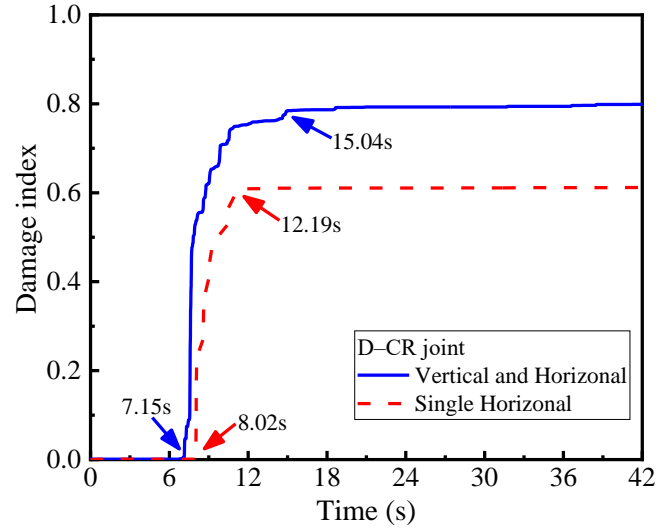

(a) Compression damage time history of the D-CR joints

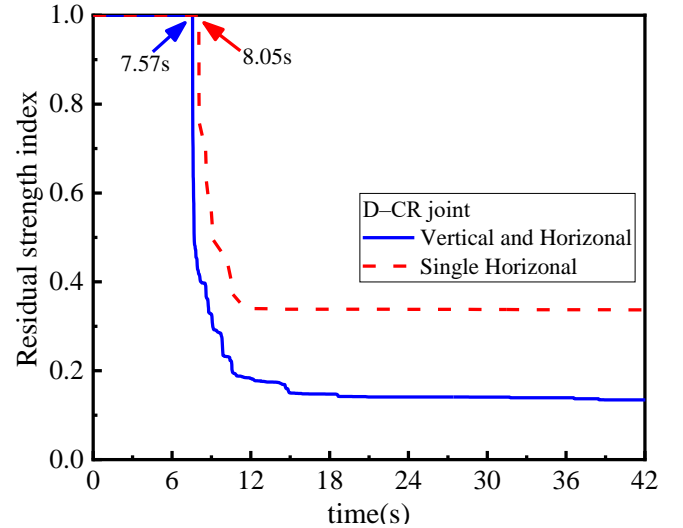

(b) Strength degradation time history of the D-CR joints

Figure 19. Compression damage and strength degradation time history of the D-CR joints.

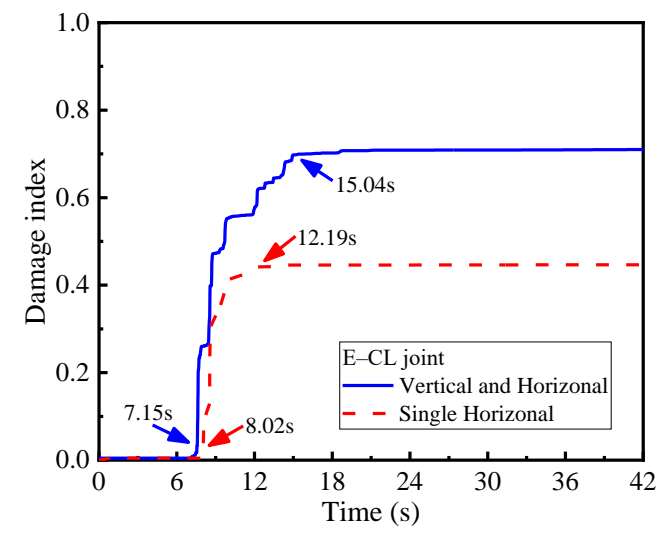

(a) Compression damage time history of the E-CL joints

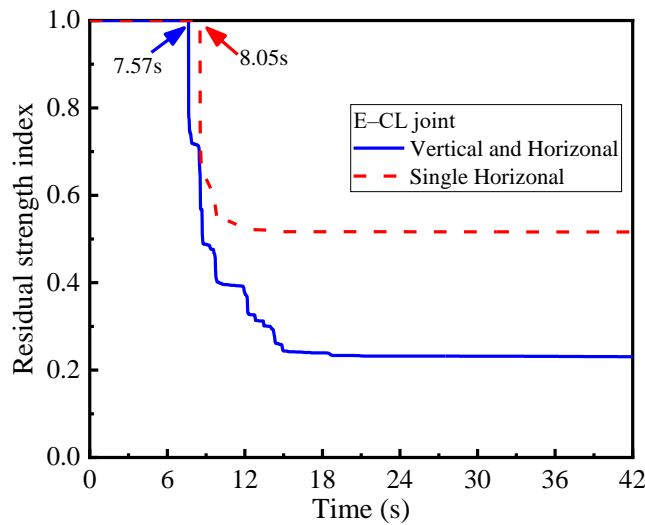

(b) Strength degradation time history of the E-CL joints

Figure 20. Compression damage and strength degradation time history of the E-CL joints.

\section{Conclusions}

The dynamic response characteristics of a fabricated station structure with different ground motion characteristics, seismic intensities, and seismic conditions were compared and analyzed. The results showed that the fabricated station structure as a new subway station structure had obvious differences in the structural characteristics compared with the cast-in-place station structure. However, the seismic response of the fabricated station structure was universal under different earthquake actions. The following conclusions were obtained from the numerical results:

(1) The maximum impact rates of the vault or bottom plate joints on structural failure, interlayer relative deformation, and internal force were $3.2 \%, 0.7 \%$, and $6.83 \%$, respectively, under the action of different seismic characteristics. The maximum impact rates of the fully prefabricated vault or bottom plate on structural failure, maximum interlayer relative deformation, and internal force of section were $3.05 \%, 0.17 \%$, and $4.62 \%$, respectively, under different seismic conditions. The maximum influence rates of the fully prefabricated vault or bottom plate on structural failure, maximum interlayer relative deformation, and internal force were $11.26 \%, 0.92 \%$, and $5.23 \%$, respectively, under the action of different earthquake intensities. The influence of the connection joints in the vault or bottom plate on the seismic response of the fabricated station structure could be ignored. Under the action of an earthquake, the underground structure deformed under the constraint of the surrounding soil. The most serious damage to the prefabricated structure lay in the B-C joints. The joints of the vault and the bottom plate were always in the extrusion state, as 
in the cast-in-place structure. It is recommended that the assembly scheme with fewer prefabricated components is used to improve the construction efficiency under the premise of meeting the requirements of the work site and mechanical capacity.

(2) The joint damage assessment method proposed in this study quantified the damage degree of dry-type connection joints and visually reflected the seismic response of fabricated station structures. The vertical seismic component significantly influenced the seismic response of the fabricated structures, especially the $\mathrm{B}-\mathrm{C}$ joint. The vertical seismic component increased the joints' maximum compression damage index by $19 \%$ and reduced the residual strength index by $83 \%$. The vertical seismic component increased the axial compression ratio of the sidewalls, which made the damage of the $\mathrm{B}-\mathrm{C}$ joints more severe. The vertical seismic component should be considered in the seismic design of prefabricated station structures. At the same time, the B-C joints should also be reinforced.

Although the seismic response of a fabricated station structure with different joint distribution forms was studied and the effect mechanism of connecting joints was clarified in this study, for the optimization of joint distribution, only seismic loads were considered, and the transportation conditions, field production, and mechanical equipment were not taken into account. Comprehensive optimization of the joints not only involves the performance of the joints but also needs to consider the problems of design, construction, and other professional factors, as well as firefighting, waterproofing, and other issues.

Author Contributions: Conceptualization, methodology, and software: H.H.; resources, project administration, funding acquisition: Z.L. All authors have read and agreed to the published version of the manuscript.

Funding: This research is funded by Fundamental Research Funds for the Central Universities (No. C20JB500160), the National Natural Science Foundation of China (No. 51678033). Their support is gratefully acknowledged.

Institutional Review Board Statement: Not applicable.

Informed Consent Statement: Not applicable.

Conflicts of Interest: The authors declare no conflict of interest.

\section{References}

1. Cai, X.; Yang, C.; Yuan, Y. Hybrid Simulation of Seismic Responses of a Typical Station with a Reinforced Concrete Column. Appl. Sci. 2020, 10, 1331. [CrossRef]

2. Chen, Z.; Wu, J.; Liu, H. Seismic Behavior of Steel Plate-Concrete Shear Walls with Holes. Appl. Sci. 2019, 9, 5255. [CrossRef]

3. Han, S.W.; Jee, H.W. A Numerical Model for Simulating Ground Motions for the Korean Peninsula. Appl. Sci. 2020, 10, 1254. [CrossRef]

4. Lu, X.; Cheng, Q.; Xu, Z.; Xu, Y.; Sun, C. Real-Time City-Scale Time-History Analysis and Its Application in Resilience-Oriented Earthquake Emergency Responses. Appl. Sci. 2019, 9, 3497. [CrossRef]

5. Huh, J.; Tran, Q.H.; Haldar, A.; Park, I.; Ahn, J. Seismic Vulnerability Assessment of a Shallow Two-Story Underground RC Box Structure. Appl. Sci. 2017, 7, 735. [CrossRef]

6. Hashash, Y.M.A.; Hook, J.J.; Schmidt, B.; Yao, I.C. Seismic design and analysis of underground structures. Tunn. Undergr. Space Technol. Inc. Trenchless Technol. Res. 2001, 16, 247-293. [CrossRef]

7. Kawajima, K. Seismic Design of Underground Structure; Kajima Institute Publishing: Tokyo, Japan, 1994.

8. Ma, C.; Lu, D.; Du, X. Seismic performance upgrading for underground structures by introducing sliding isolation bearings. Tunn. Undergr. Space Technol. 2018, 74, 1-9. [CrossRef]

9. Li, W.; Chen, Q. Seismic performance and failure mechanism of a subway station based on nonlinear finite element analysis. Ksce J. Civ. Eng. 2018, 22, 1-12. [CrossRef]

10. Lubliner, J.; Oliver, J.; Oller, S.; O Ate, E. A plastic-damage model for concrete. Int. J. Solids Struct. 1989, 25, 299-326. [CrossRef]

11. Nguyen, V.Q.; Nizamani, A.; Park, D.; Kwon, O.S. Numerical simulation of damage evolution of Daikai station during the 1995 Kobe earthquake. Eng. Struct. 2020, 206, 110180. [CrossRef]

12. Khani, S.; Homami, P. Seismic Performance of underground Shallow Subway Stations in Soft Soil. J. Eng. Geol. 2014, 8, 1983-2002.

13. Li, B.; Wang, Z.Z. Numerical study on the response of ground movements to construction activities of a metro station using the pile-beam-arch method. Tunn. Undergr. Space Technol. 2019, 88, 209-220. [CrossRef]

14. Kheradi, H.; Ye, B.; Nishi, H.; Oka, R.; Zhang, F. Optimum pattern of ground improvement for enhancing seismic resistance of existing box culvert buried in soft ground. Tunn. Undergr. Space Technol. 2017, 69, 187-202. [CrossRef] 
15. Ma, C.; Lu, D.C.; Du, X.L.; Qi, C.Z.; Zhang, X.Y. Structural components functionalities and failure mechanism of rectangular underground structures during earthquakes. Soil Dyn. Earthq. Eng. 2019, 119, 265-280. [CrossRef]

16. Qiu, D.; Chen, J.; Xu, Q. Comparative numerical analysis on dynamic effects of underground large scale frame structures under seismic waves. Tunn. Undergr. Space Technol. 2019, 83, 35-50. [CrossRef]

17. Liu, Z.; Chen, Z.; Liang, S.; Li, C. Isolation mechanism of a subway station structure with flexible devices at column ends obtained in shaking-table tests. Tunn. Undergr. Space Technol. 2020, 98, 103328. [CrossRef]

18. Bao, Y.; Becker, T.C.; Hamaguchi, H. Failure of double friction pendulum bearings under pulse-type motions. Earthq. Eng. Struct. Dyn. 2017, 46, 715-732. [CrossRef]

19. Harvey, P.S.; Kelly, K.C. A review of rolling-type seismic isolation: Historical development and future directions. Eng. Struct. 2016, 125, 521-531. [CrossRef]

20. Sarlis, A.A.; Constantinou, M.C. A model of triple friction pendulum bearing for general geometric and frictional parameters. Earthq. Eng. Struct. Dyn. 2016, 45, 1837-1853. [CrossRef]

21. Tsai, C.S.; Lin, Y.C.; Chen, W.S. Seismic Behavior of High-Tech Facility Isolated With a Trench Friction Pendulum System. In Proceedings of the ASME Pressure Vessels and Piping/ICPVT-11 Conference, Vancouver, BC, Canada, 23-27 July 2006.

22. Koyama, Y. Present status and technology of shield tunneling method in Japan. Tunn. Undergr. Space Technol. Inc. Trenchless Technol. Res. 2003, 18, 145-159. [CrossRef]

23. Li, P.; Wei, Y.; Zhang, M.; Huang, Q.; Wang, F. Influence of non-associated flow rule on passive face instability for shallow shield tunnels. Tunn. Undergr. Space Technol. 2022, 119, 104202. [CrossRef]

24. Fang, Q.; Wang, G.; Yu, F.; Du, J. Analytical algorithm for longitudinal deformation profile of a deep tunnel. J. Rock Mech. Geotech. Eng. 2021, 13, 845-854. [CrossRef]

25. Xu, X.; Li, Z.; Fang, Q.; Zheng, H. Challenges and countermeasures for using pile-beam-arch approach to enlarge large-diameter shield tunnel to subway station. Tunn. Undergr. Space Technol. 2020, 98, 103326. [CrossRef]

26. Zheng, H.; Li, P.; Ma, G.; Zhang, Q. Experimental investigation of mechanical characteristics for linings of twins tunnels with asymmetric cross-section. Tunn. Undergr. Space Technol. 2022, 119, 104209. [CrossRef]

27. Qian, F.; Zhang, D.; Li, Q.Q.; Wong, L. Effects of twin tunnels construction beneath existing shield-driven twin tunnels. Tunn. Undergr. Space Technol. 2015, 45, 128-137.

28. Yang, X.; Lin, F. Prefabrication technology for underground metro station structure. Tunn. Undergr. Space Technol. 2021, 108, 103717. [CrossRef]

29. Li, Z.; Chen, W.; Su, H.; Shi, S. An experiment Study on the evolution law of concrete structure crack and joint seam deformation for tenon groove joints in the prefabricated metro station. China Civ. Eng. J. 2015, 48, 409-413.

30. Li, Z.; Su, H.; Lu, S.; Wang, C.; Xu, X. Experimental study on flexural mechanical properties of the double tenon groove joints of prefabricated subway station. China Civ. Eng. J. 2017, 50, 28-32.

31. Ding, P.; Tao, L.; Yang, X.; Zhao, J.; Shi, C. Three-dimensional dynamic response analysis of a single-ring structure in a prefabricated subway station. Sustain. Cities Soc. 2019, 45, 271-286. [CrossRef]

32. Tao, L.; Ding, P.; Shi, C.; Wu, X.; Wu, S.; Li, S. Shaking table test on seismic response characteristics of prefabricated subway station structure. Tunn. Undergr. Space Technol. 2019, 91, 102994. [CrossRef]

33. Tao, L.; Ding, P.; Yang, X.; Lin, P.; Shi, C.; Bao, Y.; Wei, P.; Zhao, J. Comparative study of the seismic performance of prefabricated and cast-in-place subway station structures by shaking table test. Tunn. Undergr. Space Technol. 2020, 105, 103583. [CrossRef]

34. Qiu, D.; Chen, J.; Xu, Q. 3-D numerical analysis on seismic responses of the underground large scale frame structure under near-fault ground motions. Tunn. Undergr. Space Technol. 2019, 91, 103020. [CrossRef]

35. Liu, J.; Wang, Z.; Du, X. 3D viscous-spring artificial boundary in time domain. Earthq. Eng. Eng. Vib. 2006, 5, 93-102. [CrossRef]

36. Gao, Z.; Zhao, M.; Du, X.; Zhong, Z. A generalized response spectrum method for seismic response analysis of underground structure combined with viscous-spring artificial boundary. Soil Dyn. Earthq. Eng. 2021, 140, 106451. [CrossRef]

37. Jian-Tao, H.; Huai-Fa, M.; Zhang, B.Y.; Chen, H.Q. Method and realization of seismic motion input of viscous-spring boundary. J. Hydraul. Eng. 2010, 41, 960-969.

38. Island, R. Version ABAQUS. 6.14 Document; USA, 2014. Available online: http://130.149.89.49:2080/v6.14/ (accessed on 12 December 2021).

39. Zhuang, H.; Hu, Z.; Wang, X.; Chen, G. Seismic responses of a large underground structure in liquefied soils by FEM numerical modelling. Bull. Earthq. Eng. 2015, 13, 3645-3668. [CrossRef]

40. Kim, D.-K.; Yun, C.-B. Time-domain soil-structure interaction analysis in two-dimensional medium based on analytical frequencydependent infinite elements. Int. J. Numer. Methods Eng. 2000, 47, 1241-1261. [CrossRef]

41. Wolf, J.P. Soil-structure-interaction analysis in time domain. Nucl. Eng. Des. 1989, 111, 381-393. [CrossRef]

42. Li, Z.; Wang, C.; Su, H.; Shi, S.; Wang, P. Mechanical Property of Tenon-Groove Joints for Metro Station Constructed by Prefabricated Structure. China Railw. Sci. 2015, 36, 7-11.

43. Huo, H.; Bobet, A.; Fernández, G.; Ramírez, J. Load Transfer Mechanisms between Underground Structure and Surrounding Ground: Evaluation of the Failure of the Daikai Station. J. Geotech. Geoenviron. Eng. 2005, 131, 1522-1533. [CrossRef]

44. Rashiddel, A.; Koopialipoor, M.; Hadei, M.R.; Rahmannejad, R. Numerical Investigation of Closed-Form Solutions for Seismic Design of a Circular Tunnel Lining (by Quasi-Static Method). Civ. Eng. J. 2018, 4, 239. [CrossRef] 
45. Bardet, J.P.; Ichii, K.; Lin, C.H. EERA-A Computer Program for Equivalent-Linear Earthquake site Response Analyses of Layered Soil Deposits; 2000. Available online: https:/ /www.worldcat.org/title/eera-a-computer-program-for-equivalent-linearearthquake-site-response-analyses-of-layered-soil-deposits/oclc/45142158 (accessed on 12 December 2021).

46. Xu, Z.; Du, X.; Xu, C.; Hao, H.; Bi, K.; Jiang, J. Numerical research on seismic response characteristics of shallow buried rectangular underground structure. Soil Dyn. Earthq. Eng. 2019, 116, 242-252. [CrossRef]

47. Wang, H.F.; Lou, M.L.; Zhang, R.L. Selection of Rayleigh Damping Coefficients for Seismic Response Analysis of Soil Layers. Int. J. Geol. Environ. Eng. 2017, 11, 158-163.

48. Makris, N.; Zhang, J. Time-domain viscoelastic analysis of earth structures. Earthq. Eng. Struct. Dyn. 2015, 29, 745-768. [CrossRef]

49. Liu, H.; Xu, C.; Du, X. Seismic response analysis of assembled monolithic subway station in the transverse direction. Eng. Struct. 2020, 219, 110970. [CrossRef]

50. Wang, J.; Liu, H.; Liu, H.; Zou, Y. Centrifuge model study on the seismic responses of shield tunnel. Tunn. Undergr. Space Technol. 2019, 92, 103036. [CrossRef]

51. Li, W.; Chen, Q. Effect of vertical ground motions and overburden depth on the seismic responses of large underground structures. Eng. Struct. 2020, 205, 110071-110073. [CrossRef]

52. Jiang, J.; Xu, C.; El Naggar, H.M.; Du, X.; Xu, Z.; Assaf, J. Improved pushover method for seismic analysis of shallow buried underground rectangular frame structure. Soil Dyn. Earthq. Eng. 2021, 140, 106363. [CrossRef]

53. Lu, Q.R.; Wang, Z.L.; Gao, J.H.; Chang, Y. Influence of seismic parameters on the performance of underground structures. In Proceedings of the 6th International Conference on Energy and Environmental Protection, Zhuhai, China, 29-30 June 2017; Volume 143, pp. 101-107.

54. Yu, Y.; Wang, S.F.; Niu, F.L. Analysis of common cause failure effect on system reliability in seismic PSA. Prog. Nucl. Energy 2014, 75, 158-167. [CrossRef]

55. Fu, J.Q.; Wang, R.; Zhou, Q.G. Based on ArcGIS Interpolation Method of Drawing Peak Acceleration Zoning Map. In Proceedings of the 13th International Symposium on Computational Intelligence and Design, Hangzhou, China, 12-13 December 2020; pp. 380-383.

56. Kappos, L.; Eng, D. Seismic damage indices for RC buildings: Evaluation of concepts and procedures. Prog. Struct. Eng. Mater. 2010, 1, 78-87. [CrossRef] 